\title{
Coalfield structure and structural controls on coal in China
}

\author{
Daiyong Cao ${ }^{1} \cdot$ Anmin $\mathrm{Wang}^{1} \cdot$ Shuzheng $\mathrm{Ning}^{2} \cdot$ Huantong $\mathrm{Li}^{3} \cdot \mathrm{Aijun}^{\mathrm{Guo}}{ }^{2} \cdot$ \\ Limin Chen ${ }^{1} \cdot$ Kang Liu ${ }^{1} \cdot$ Jieqing Tan $^{4} \cdot$ Zhihong Zheng $^{5}$
}

Received: 18 June 2019/Revised: 7 November 2019/Accepted: 6 May 2020/Published online: 20 May 2020

(C) The Author(s) 2020

\begin{abstract}
The occurrence of coal-bearing strata in a variety of coal-bearing basins of China is characterized by late tectonic deformation and remarkable spatial and geochronologic differences. The main controlling factors, which determine the tectonic framework of coalfields, include the geodynamic environment, tectonic evolution, deep structures, tectonic stress, and lithologic combination of the coal measures. The Chinese continent has experienced multi-stage tectonic movements since the Late Paleozoic. The spatial and temporal heterogeneity of its continental tectonic evolution, the complexity of its basement properties, and its stratigraphic configurations control the tectonic framework of its coalfields' present complex and orderly patterns. The concept of coal occurrence structural units is proposed in this paper and is defined as the structural zoning of coal occurrence. China's coalfields are divided into five coal occurrence structural areas, and the structural characteristics of the coalfields in five main coal occurrence areas throughout the country are summarized. Based on the analysis of the relationship between the structure characteristics and occurrence of coal in these coalfields, the coal-controlling structures are divided into six groups: extensional structural styles, compressional structural styles, shearing and rotational structural styles, inverted structural styles, sliding structural styles, and syn-depositional structural styles. In addition, the distribution of coal-controlling structural styles is briefly summarized in this paper.
\end{abstract}

Keywords Coalfield structures · Coal-controlling structures · Coal occurrence structural units - Types of coal-bearing basins $\cdot$ Coal-controlling structural styles

Daiyong Cao

cdycumtb@163.com; cdy@cumtb.edu.cn

1 College of Geoscience and Surveying Engineering, China University of Mining and Technology, Beijing, Beijing 100083, China

2 China National Administration of Coal Geology, Beijing 100039, China

3 Xi'an University of Science and Technology, Xi'an 710054, China

4 Sichuan Coalfield Geology Bureau, Chengdu 610072, China

5 Strategic Research Center of Oil and Gas Resources, Ministry of Land and Resources, Beijing 100034, China

\section{Introduction}

China is a complex continent consisting of several stable blocks and active belts. The stable blocks, which have relatively small scales, have a low degree of rigidity and highly deformed sedimentary cap rocks (Ma 1992; Wan 2011; Che et al. 2012). Compared with coalfields developed in a single continent, like North America or Europe, the coal-bearing basins in China have experienced a more complex geological evolution (Wang et al. 2007; Cao 2018). The geology of China's coalfields is characterized by various types of coal-bearing basins, the later deformation of coal measures, and the complex occurrence of coal.

Tectonic movement is the primary geological factor controlling the formation and deformation of coal, coal seams, coal systems, and coal basins. (1) The tectonic 
depressions formed by crustal movement provide a suitable place for the deposition of coal measures. (2) The tectonically uplifted areas provide the material sources for the sedimentary deposition of coal basins. (3) The regional structure in the coal-forming periods determined the distribution of the coal enrichment belt. (4) The structural movement controls the prosperity of coal-forming plants because it affects the paleoclimate and paleogeographic conditions. (5) The tectonic-thermal evolution of the coal basins promotes the progress of coalification. (6) The folds and faults generated after coal formation destroy the integrity of the coal measures and coal seams by cutting a coalfield into several segments of varying sizes. Thus, the tectonic movements not only affect the direction of coal exploration but also determine the difficulty of exploration and development. Consequently, the study of coalfield structures is a fundamental stage in the evaluation and exploration of coal resources (Cao et al. 1999, 2013; Cheng et al. 2010).

\section{Basic features of Chinese coalfield structures}

Since the Late Paleozoic, the Chinese continent has successively experienced the Paleo-Asia geodynamic system (Ren et al. 1990), the Pacific geodynamic system, and the Tethys geodynamic system. The spatial and temporal heterogeneity of its continental tectonic evolution, the complexity of its basement properties, and its stratigraphic configuration determine the tectonic framework of the coalfields' present complex and orderly patterns. The regional tectonic factors that control the framework of Chinese coalfield structures include a first-level belt (the north-south trending Helan-Taihang-Ailao mountains structural belt) and three second-level belts (the Altay-Yin mountains structural belt, the Kunlun-Qinling-Dabie mountains structural belt, and the Greater Khingan-Taihang-Wuling mountains structural belt). Similar to the structure of the Chinese continental lithosphere (Li 2006), the tectonic framework of Chinese coalfields can be divided into two major coalfield tectonic regions, three coal measure deformation zones, and five coal occurrence areas (Fig. 1).

\subsection{Two major coalfield tectonic regions}

The Chinese continent is divided into the eastern coalfield tectonic region and the western coalfield tectonic region by the north-south trending Helan-Longmen Mountains structural belt.

(1) The eastern coalfield tectonic region includes two deformation zones, the eastern compound deformation zone and the middle transitional deformation zone, and three structural areas, the Northeast, North, and South coal occurrence structural areas. This region is characterized by multiple coalbearing strata, a diversity of coal-bearing basins, the complicated evolution of its coal-bearing basins, the complicated deformation of its coal measures, and remarkable spatial and temporal differences. The basic distribution framework of the coalfield structures has an NE-NNE trend.

(2) The western coalfield tectonic region has a scope similar to that of the western compressional deformation zone, and it includes the northwest coal occurrence structural area and the Yunnan-Tibet coal occurrence structural area. The Early-Middle Jurassic coal measures are distinctly superior in these areas, with inland lakes as the main coal accumulating environment. The formation and deformation of the coal-bearing basins were controlled by the Tethys geodynamic system, and the basins exhibit evidence of conspicuous structural inversion during the Cenozoic. Taking compressional structures as the main structural styles, the coalfield structures are NW-WNW trending.

\subsection{Three structural assemblage zones} of the deformation of coal measures

(1) Eastern compound deformation zone. The later deformation of the coal measures was significant and diverse east of the Greater Khingan-Taihang-Wuling Mountains. Deformation mainly took place in compressional environments south of the QinlingDabie Mountains and in extensional environments in Northern China and Northeastern China. The basic framework of the structural assemblage of the deformation of the coal measures is characterized by parallel NE-NNE trending structures, and the extent and intensity of the deformation decreasing from east to west.

(2) Western compressional deformation zone. The structural framework of the coalfields west of the HelanLongmen Mountains is characterized by compression. The distribution of the coalfield structures exhibits an NW-WNW-NNW arc shape, and the intensity of the deformation decreases northward. The structural assemblage of the deformation of the coal measures transitions from a parallel banding pattern in the Yunnan-Tibet coal occurrence structural area to a multicenter annular pattern in the northwest coal occurrence structural area. 


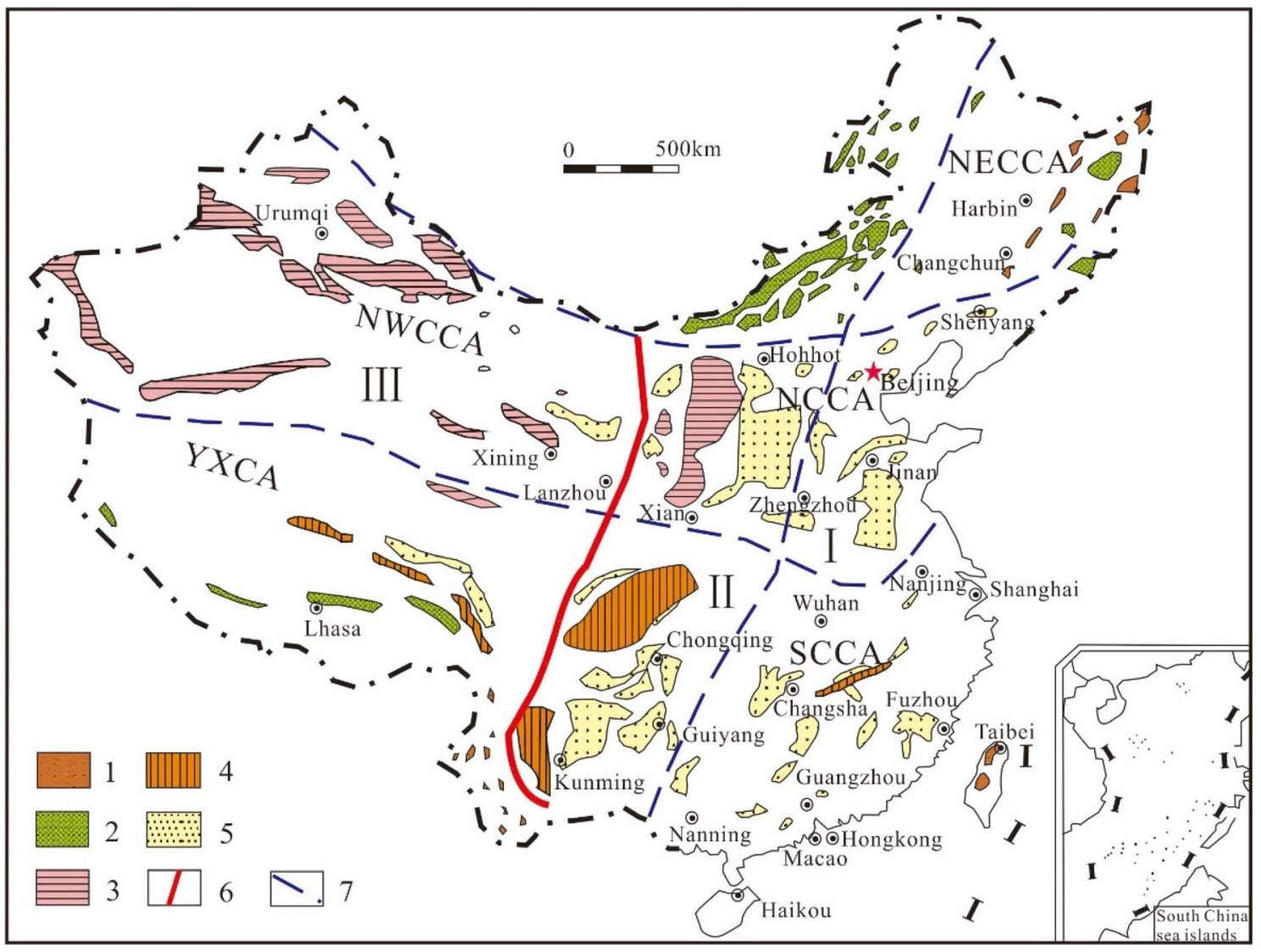

Fig. 1 Tectonic framework of coalfields in China. 1-Carboniferous-Permian coal measure; 2-Upper Triassic coal measure; 3-Early-Middle Jurassic coal measure; 4-Lower Cretaceous coal measure; 5-Paleogene-Neogene coal measure; 6-first-level structural boundary; 7-second-level structural boundary; I: Eastern compound deformation zone; II: Western compressional deformation zone; III: Middle transitional deformation zone; NECCA: North East China coal occurrence area; NCCA: North China coal occurrence area; NWCCA: Northwest China coal occurrence Area; SCCA: South China coal occurrence area; YXCA: Yunnan-Tibet (Xizang) China coal occurrence area

(3) Middle transitional deformation zone. This is a transitional zone between the Helan-Longmen Mountains structural belt and the Greater KhinganTaihang-Wuling Mountains structural belt. The structure of the crust is stable, and the evolution of the coal-bearing basins shows its tectonic heritage. The structural assemblages of the deformation of the coal measures in the Ordos Basin and the Sichuan Basin exhibit a typical Platform concentric annular structure.

\subsection{Five coal occurrence structural areas}

Two east-west trending first-level structural belts, the Yinshan-Yanshan orogenic belt and the Kunlun-Qinlin orogenic belt, together with a north-south trending firstlevel structural belt divide the continent into five main coal occurrence structural areas. These areas are the Northeast China coal occurrence structural area, the North China coal occurrence structural area, the Northwest China coal occurrence structural area, the South China coal occurrence structural area, and the Yunnan-Tibet coal occurrence structural area. These structural belts and structural areas form the basic architecture and structural framework of the coal fields in China.

\section{Division of the coal occurrence structural units}

\subsection{Concept of coal occurrence structural unit}

The distribution of coal measures and coal seams is characterized by zoning and banding and is largely controlled by the present-day regional tectonic framework. A coal occurrence structural unit is an important concept that has been proposed by previous studies of coalfield structures throughout the country, which is part of the work of the National Potential Evaluation of Coal Resources (Cao et al. 2013, 2016; Cheng et al. 2016). According to the requirement for the evaluation and exploration of coal resources, it is used to describe the regional tectonic framework and 
tectonic evaluation control of the occurrence of coal measures, and it highlights the current occurrence status of coal measures that have experienced multi-period tectonic activity during long-term geological history.

The division of the coal occurrence structural units is mainly based on the accumulation characteristics, current occurrence characteristics, and the present-day regional tectonic setting of the coal measures. This division indicates the controlling effect of structural features on the formation and deformation of coal measures, and it can be used to summarize the spatial distribution of coalfield structures. The coal occurrence structural units can be defined as the structural units divided by the occurrence of the coal measures in the same or similar coal-bearing strata. These structural units are a combination of strata and structures, which have similar structural features at present and experienced approximately the same tectonic evolution. They also reflect the structural characteristics of the preservation of coal resources in the present day. It has the dual characteristics of a coal occurrence unit and a tectonic unit. On the one hand, it is the structural division of the occurrence of coal measures and has the general meaning of a tectonic unit. On the other hand, it reflects the occurrence of coal measures and has the meaning of a coal occurrence unit.

\subsection{Gradation of coal occurrence structural units}

Coal occurrence structural units are tectonic units divided by the occurrence of coal measures. Concerning the geological control of structures on the current occurrence of coal measures, coal-cumulating structural units can be divided into three levels according to their scale, coal occurrence structural area (COSA), coal occurrence structural subarea (COSS), and coal occurrence structural belt (COSB).

The coal occurrence structural area is the first order of coal occurrence structural units, which is divided by the tectonic framework of the main coal-forming geological period and the occurrence of coal measures. It has a scope similar to that of a first-order tectonic unit and can cross the first-order tectonic unit. Based on a long-time practice, Chinese geologists have divided China into five coal occurrence structural areas, the Northeast China, North China, Northwest China, South China, and Yunnan-Tibet coal occurrence structural areas. These structural areas exhibit spatial and temporal differences in the occurrence of coal resources in China. In this paper, the first order coal occurrence structural units have the same division as the coal occurrence areas.

The second-order coal occurrence structural units, i.e., the coal occurrence structural subareas, can be divided based on the deformation characteristics of the coal measures. The coal occurrence structural belts in each subarea have similar tectonic evolutions and deformation of coal measures, with regionally large faults as the main controlling boundaries.

The third order of coal occurrence structural units is called a coal occurrence structural belt, which is formed by later deformation of coal occurrence basins or basin groups. The division was made based on five aspects. First, they have the same accumulating law of coal resources and belong to the same coal occurrence basin or basin group. Second, they experienced a similar tectonic-thermal evolution. Third, coal measures with the same geological age have similar tectonic frameworks due to similar occurrence conditions. Fourth, the range of a coal occurrence structural belt is always delineated by regional tectonic lines and the sedimentary boundaries of the coal measures. Fifth, coal occurrence structural belts generally correspond to thirdorder tectonic units, but they can also cross different levels of tectonic units through the development and distribution of coal measures. Coal occurrence structural belts are named using a dual nomenclature, which is a combination of its geographical name and its structural properties. This method reflects the basic features of the tectonic framework of coalfields. Coal occurrence structural units that are under third level use a common terminology that is used for the division of basin structures (i.e., uplift/sag, faultuplift/fault-sag, salient/depression) and reflects the characteristics of the occurrence of the coal measures.

According to the definition and division of the coal occurrence structural units, China can be divided into 5 coal occurrence structural areas, 15 coal occurrence structural subareas, and 74 coal occurrence structural belts (Fig. 2, Table 1).

\section{Summary of the main coal occurrence structural units}

\subsection{Northeast China coal occurrence structural area}

The Northeast China COSA tectonically belongs to the eastern part of the Tianshan-Xingmeng orogenic system, and the southern part of it overlies the northern edge of the North China block. This area mainly contains Early Cretaceous coal-bearing basins, but it also contains Cenozoic, Early Mesozoic, and Late Paleozoic coal-bearing basins. The coal-bearing strata are mainly Late Jurassic and Early Cretaceous.

With the Xingmeng orogenic system and inner blocks as basement, the Northeast China COSA was involved in the active continental margin of the peri-Pacific after the Indosinian movement. During the early and middle stages of the Yanshan movement, this area was characterized by 


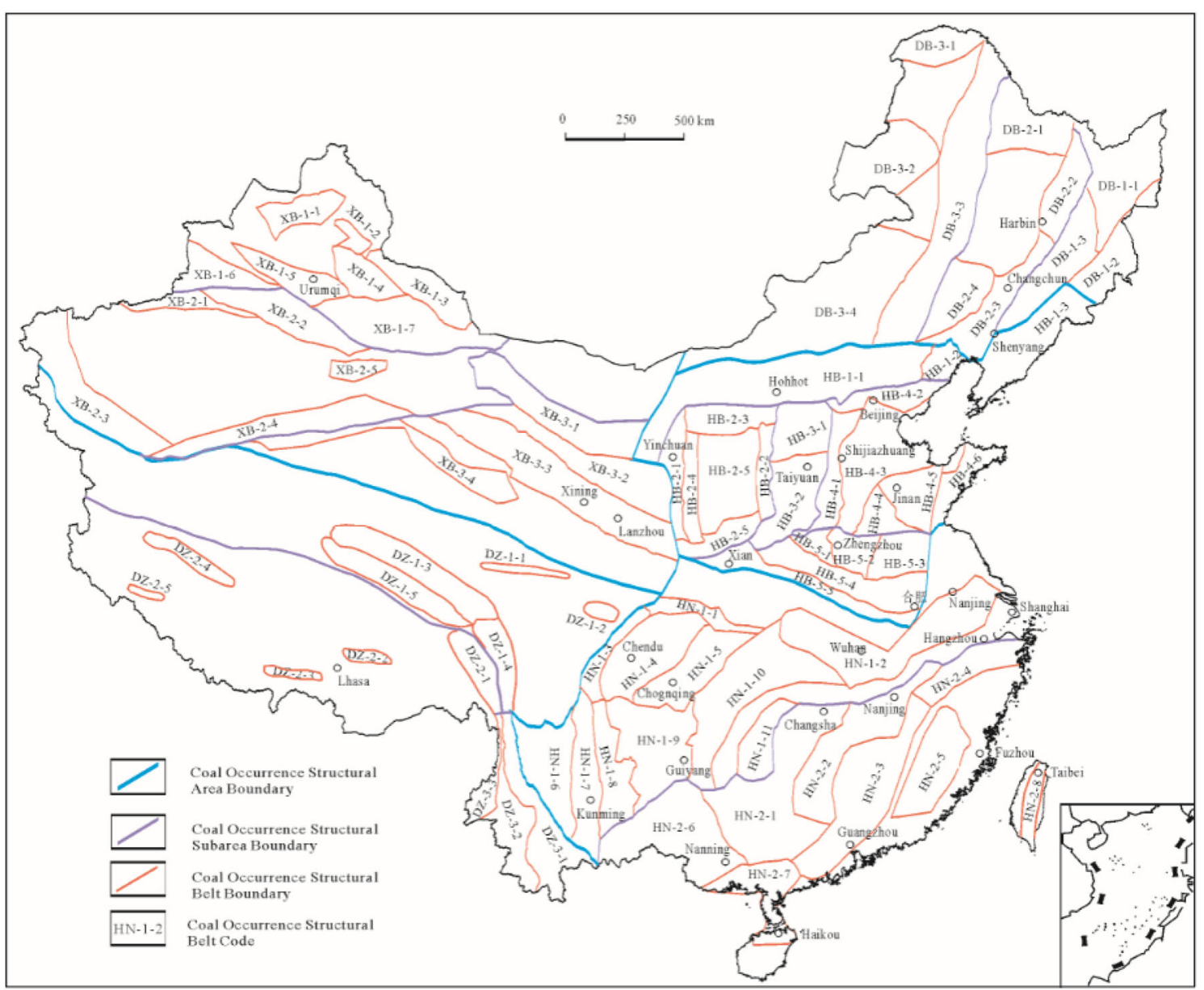

Fig. 2 Division of the coal occurrence structural units in China

NNE-SSW trending compressional tectonics, and the tectonic evolution of eastern China entered a faulting stage at the continental margin with East Asia in the Late Mesozoic. Later deformation of the Mesozoic coal measures was mainly due to coal-controlling faults and was characterized by the movement of fault blocks. A half-graben rift, which is controlled by a listric normal fault, together with a graben-horst structure, is the primary structural pattern. The regional tectonic lines exhibit a NE-SW trend (Fig. 3), and the intensity of the deformation increases from west to east.

The Northeast China coal occurrence structural area (COSA) can be divided into three coal occurrence subareas (COSS) and eleven coal occurrence structural belts (COSB). In the eastern COSS, compressive structural patterns, like thrust faults extending toward the northwest and inclined folds with axial planes dipping southeast, developed in the Sanjiang-Muleng River Basin group. Paleogene rift basins developed along the Yilan-Yitong fault zone and the Dunhua-Mishan fault zone east of the Songliao Basin, and most of them experienced positive inversion in the Late Himalayan epoch. In the middle
COSS, the Songliao Basin was the main body, with coal measures distributed along its edge. This body was segmented into fault blocks by Late Mesozoic faulting. In the western COSS, small NE trending fault basins are scattered throughout the Hailar Fault Basin group, the Erlian Fault Basin group, and the Greater Khingan uplift. Later tectonic movement was relatively weak, and the extensional tectonic framework of the formation of the basin is well preserved (Fig. 4).

\subsection{North China coal occurrence structural area}

The North China coal occurrence structural area is located in the main part of the North China craton and is surrounded by tectonically active belts. The tectonic framework of the coalfields has an incomplete concentric annular structure of deformation zones (Cao et al. 1998), and the intensity of deformation decreases from the edge of the basin to the interior (Fig. 5). Carboniferous-Permian coal measures are widely developed in this area, followed by Early-Middle Jurassic coal measures in the western and northern parts, Late Triassic coal measures in the Ordos 
Table 1 Division of the coal occurrence structural units in China

\begin{tabular}{|c|c|c|}
\hline Coal occurrence structural area & Coal occurrence structural subarea & Coal occurrence structural belt \\
\hline \multirow[t]{3}{*}{$\begin{array}{l}\text { Northeast China coal occurrence } \\
\text { structural area (DB) }\end{array}$} & $\begin{array}{l}\text { Eastern coal occurrence structural subarea } \\
\text { (DB-1) }\end{array}$ & $\begin{array}{l}\text { Sanjiang-Muleng fault-depressions (DB-1-1) } \\
\text { Hulin-Xingkai fault-depressions (DB-1-2) } \\
\text { Yishu-Dunmi fault-depressions (DB-1-3) }\end{array}$ \\
\hline & $\begin{array}{l}\text { Middle coal occurrence structural subarea } \\
\text { (DB-2) }\end{array}$ & $\begin{array}{l}\text { Heihe-Xiaoxinganling fault-depressions (DB-2-1) } \\
\text { Zhangguangcailing fault-uplifts (DB-2-2) } \\
\text { Fault terraces of the Eastern Songliao Basin (DB-2-3) } \\
\text { Fault-depressions of the Southwest Songliao Basin (DB-2-4) }\end{array}$ \\
\hline & $\begin{array}{l}\text { Western coal occurrence structural subarea } \\
\text { (DB-3) }\end{array}$ & $\begin{array}{l}\text { Mohe fault-depressions (DB-3-1) } \\
\text { Hailaer fault-depressions (DB-3-2) } \\
\text { Daxinganling fault-uplifts (DB-3-3) } \\
\text { Erlian fault-depressions (DB-3-4) }\end{array}$ \\
\hline \multirow[t]{5}{*}{$\begin{array}{l}\text { North China coal occurrence } \\
\text { structural area }(\mathrm{HB})\end{array}$} & $\begin{array}{l}\text { Northern margin of the North China coal } \\
\text { occurrence structural subarea (HB-1) }\end{array}$ & $\begin{array}{l}\text { Yinshan-Yanshan fold and thrust belt (HB-1-1) } \\
\text { Thrusts and fault-depressions of Western Liaoning Province } \\
\text { (HB-1-2) } \\
\text { Thrusts and fault-depressions of Eastern Liaoning Province- } \\
\text { Southern Jilin Province (HB-1-3) }\end{array}$ \\
\hline & $\begin{array}{l}\text { The Ordos Basin coal occurrence structural } \\
\text { subarea (HB-2) }\end{array}$ & $\begin{array}{l}\text { Western margin of the Ordos Basin (HB-2-1) } \\
\text { Eastern margin of the Ordos Basin (HB-2-2) } \\
\text { Yimeng uplifts (HB-2-3) } \\
\text { Tianhuan depressions (HB-2-4) } \\
\text { Monoclines of Northern Shanxi Province (HB-2-5) } \\
\text { Weibei fault-uplifts (HB-2-6) }\end{array}$ \\
\hline & $\begin{array}{l}\text { Shanxi block depression coal occurrence } \\
\text { structural subarea (HB-3) }\end{array}$ & $\begin{array}{l}\text { Fault-depressions of Northern Shanxi Province (HB-3-1) } \\
\text { Fault-depressions of Southern Shanxi Province (HB-3-2) }\end{array}$ \\
\hline & $\begin{array}{l}\text { Eastern North China coal occurrence } \\
\text { structural subarea (HB-4) }\end{array}$ & $\begin{array}{l}\text { Fault terraces of the Eastern Taihang Mountains (HB-4-1) } \\
\text { Folds of the Southern Yanshan Mountains (HB-4-2) } \\
\text { Fault-depressions of the North China plane (HB-4-3) } \\
\text { Fault-depressions of Southwest Shandong Province (HB-4-4) } \\
\text { Fault-depressions of Middle Shandong Province (HB-4-5) } \\
\text { Fault-depressions of Northern Shandong Province (HB-4-6) }\end{array}$ \\
\hline & $\begin{array}{l}\text { Southern North China coal occurrence } \\
\text { structural subarea (HB-5) }\end{array}$ & $\begin{array}{l}\text { Songji sliding structure (HB-5-1) } \\
\text { Fault-blocks of Eastern Henan Province (HB-5-2) } \\
\text { Xuhuai fault-blocks and thrusts (HB-5-3) } \\
\text { Thrusts of the Southern margin of North China (HB-5-4) } \\
\text { Folds of the northern Qinling-Dabie Mountains (HB-5-5) }\end{array}$ \\
\hline
\end{tabular}


Table 1 continued

\begin{tabular}{ll}
\hline Coal occurrence structural area & Coal occurrence structural subarea \\
\hline $\begin{array}{l}\text { South China coal occurrence } \\
\text { structural area (HN) }\end{array}$ & $\begin{array}{c}\text { Yangtze coal occurrence structural subarea } \\
(\mathrm{HN}-1)\end{array}$
\end{tabular}

Coal occurrence structural belt

structural area $(\mathrm{HN})$

Northwest China coal occurrence structural area $(\mathrm{XB})$
Juggar Basin coal occurrence structural subarea $(\mathrm{XB}-1)$

Tarim Basin coal occurrence structural subarea $(\mathrm{XB}-2)$

Qilianshan-Kunlun Mountains coal occurrence structural subarea (XB-3)

Yunnan-Tibet Province coal occurrence structural area (DZ)
Cathaysian coal occurrence structural subarea $(\mathrm{HN}-2)$
Northern Tibet coal occurrence structural subarea (DZ-1)

Western Yunnan coal occurrence structural subarea (DZ-2)
Thrusts of the Micangshan-Dabashan Mountains (HN-1-1) Northern margin of the Yangtze Plate (HN-1-2)

Thrusts of the Longmen Mountains (HN-1-3)

Uplifts of the south central part of Sichuan Province (HN-14)

Wide spaced anticlines of the Sichuan-Chongqing atrioventricular junctional region ( $\mathrm{HN}-1-5)$

Depressions of the Lijiang-Chuxiong regions (HN-1-6)

Fault-uplifts of the west Sichuan-Yunnan atrioventricular junctional region ( $\mathrm{HN}-1-7)$

Folds of Eastern Yunnan Province (HN-1-8)

Superposed folds of the south Sichuan-West Guizhou atrioventricular junctional region ( $\mathrm{HN}-1-9)$

Wide spaced synclines of the Chongqing-Hubei-HunanGuizhou atrioventricular junctional region (HN-1-10)

Jiangnan fault-uplift (HN-1-11)

Fault-depressions of the Hunan-Guangxi atrioventricular junctional region $(\mathrm{HN}-2-1)$

Fault-depressions of the Jiangxi-Hunan-Guangdong atrioventricular junctional region $(\mathrm{HN}-2-2)$

Depressions of the Shangrao-Anfu-Quren atrioventricular junctional region $(\mathrm{HN}-2-3)$

Depressions of the west Zhejiang-east Jiangxi atrioventricular junctional region ( $\mathrm{HN}-2-4)$

Depressions of Western Fujian Province (HN-2-5)

Youjiang folds (HN-2-6)

Leiqiong fault-depressions (HN-2-7)

Thrusts-depressions of Taiwan Province (HN-2-8)

Thrusts of the western Junggar Basin (XB-1-1)

Depressions of the northern Junggar Basin (XB-1-2)

Depressions of the Santanghu Basin (XB-1-3)

Folds and fault-uplifts of the eastern Junggar Basin (XB-1-4)

Thrusts-depressions of the southern Junggar Basin (XB-1-5)

Thrusts-depressions of the Yili Basin (XB-1-6)

Thrusts-depressions of the Tuha Basin (XB-1-7)

Thrusts-depressions of the northwest Tarim Basin (XB-2-1)

Fault-uplifts of the Middle Tianshan Mountain (XB-2-2)

Thrusts-depressions of the southwest Tarim Basin (XB-2-3)

Fault-depressions of the southeast Tarim Basin (XB-2-4)

Depressions of the northeast Tarim Basin (XB-2-5)

Alxa fault depression belt (XB-3-1)

Qilian ramp-depression belt (XB-3-2)

Hexi corridor ramp-depression belt (XB-3-3)

Northern Qaidam thrust belt (XB-3-4)

Eastern Kunlun fault-uplift belt (XB-3-5)

Qingnan-Changdu fold-thrust belt (DZ-1-1)

Tumen-Baqing fold belt (DZ-1-2)

Lanping-Puer thrust-fold belt (DZ-2-1)

Baoshan-Lincang strike-slip fault-subside belt (DZ-2-2)

Tengchong-Luxi fault depression belt (DZ-2-3) 


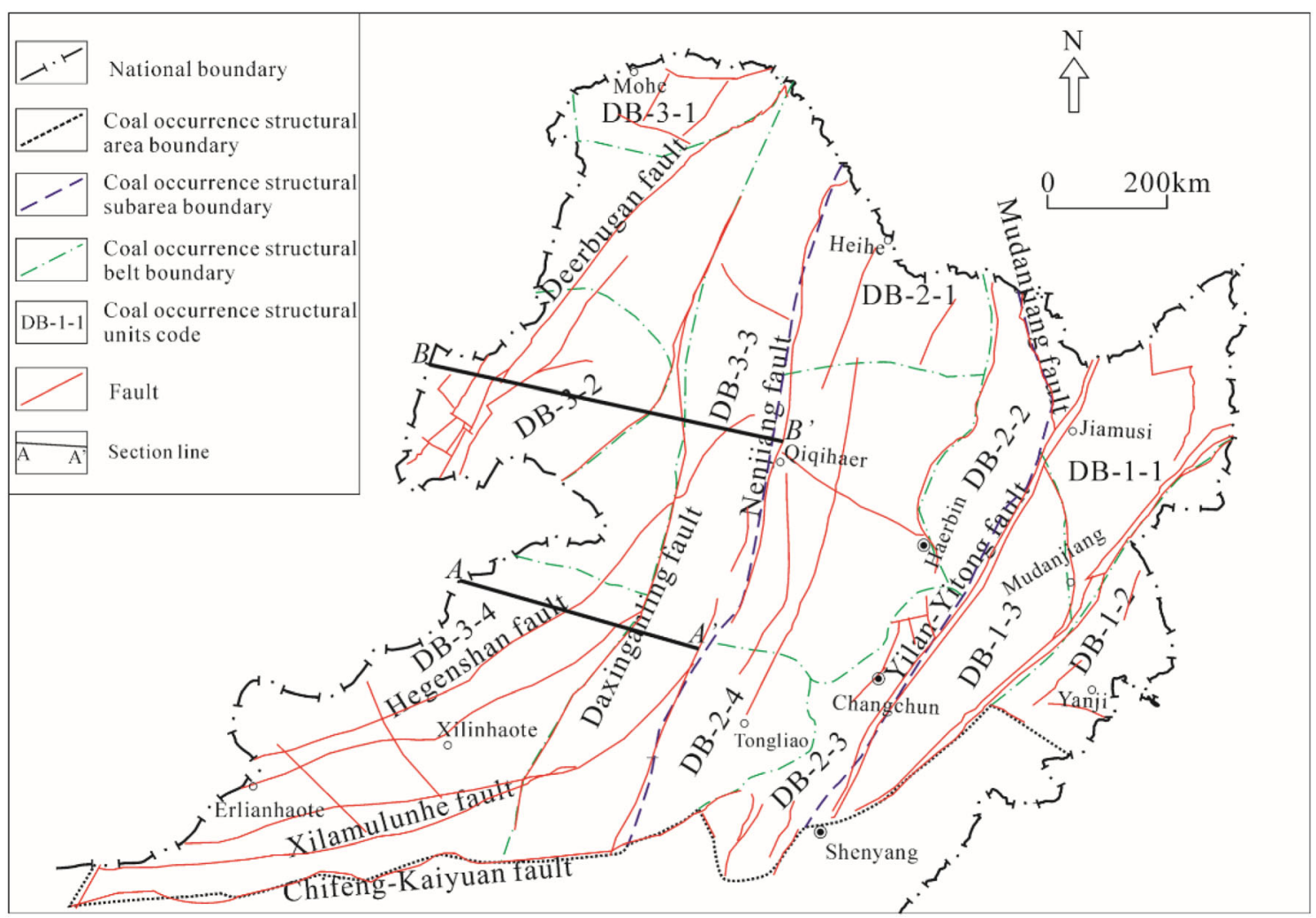

Fig. 3 Diagram of the structural outline of the Northeast China coal occurrence structural area

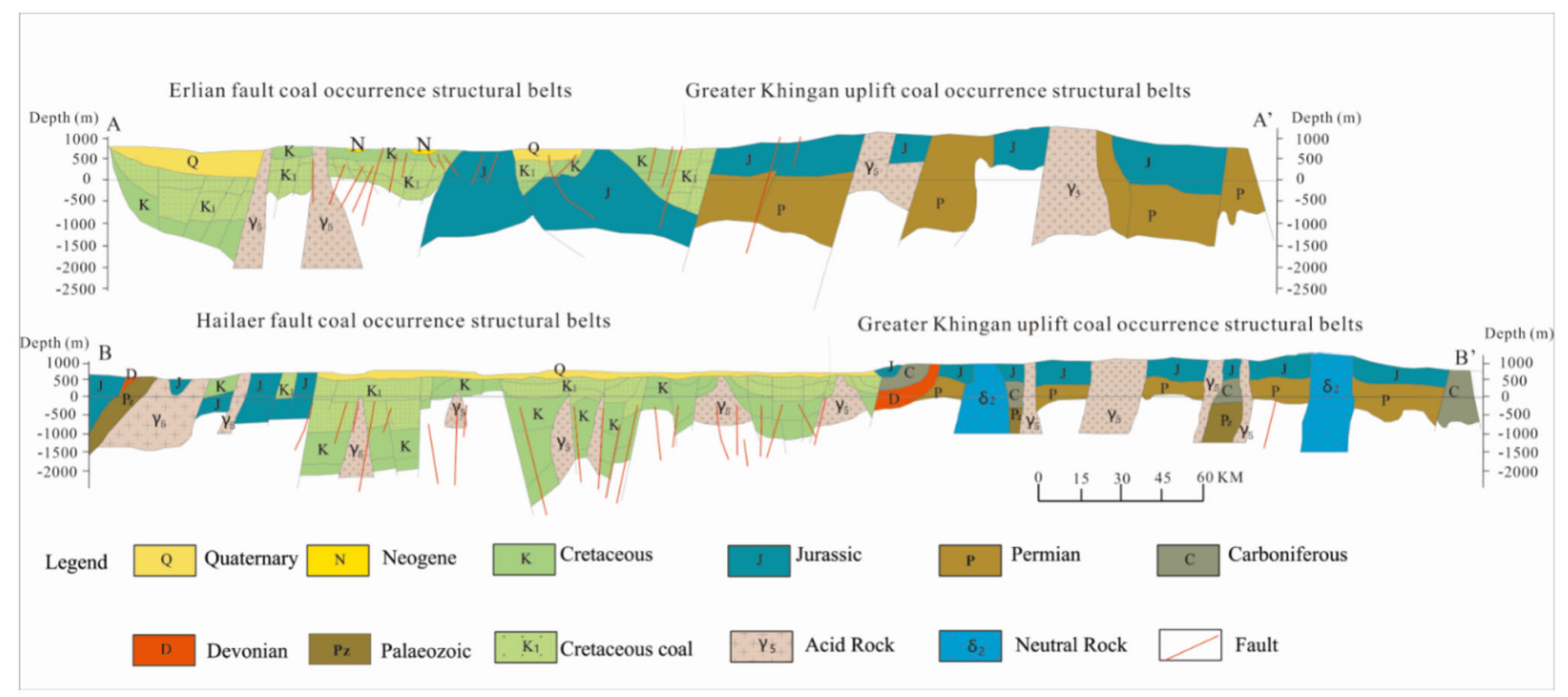

Fig. 4 Structural profile of the western subarea in the Northeast China coal occurrence structural area (section position see Fig. 3)

Basin, Lower Cretaceous and Neogene coal measures in the Yinshan-Yanshan area, and Paleogene lignite on the east coast.

The North China COSA can be divided into the northern margin of the North China COSS (HB-1), the Ordos Basin COSS (HB-2), the Shanxi block-depression COSS (HB-3), the eastern North China COSS (HB-4), and the southern North China COSS (HB-5).

(1) The Ordos Basin COSS is a complete coal occurrence structural unit composed of several coal occurrence structural belts, including a fold-thrust 


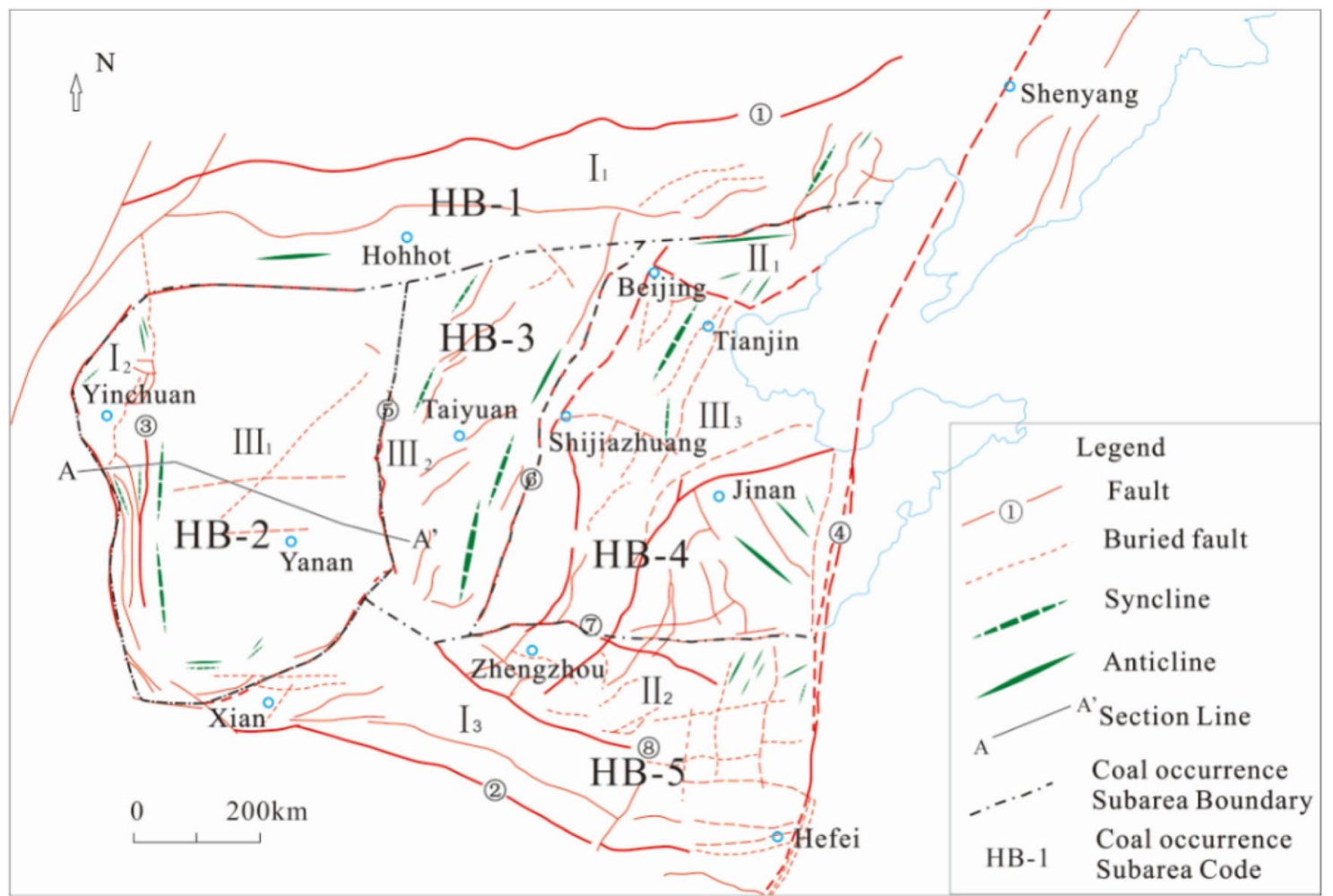

Fig. 5 Distribution of coal-controlling structures and deformation of coal measures in the North China coal occurrence structural area. (1) Northern marginal fault in the NCCA; (2) Southern marginal fault in the NCCA; (3) Western marginal fault belt in the Ordos Basin; (4) Tanlu fault; (5) Lishi fault; (6) Zijingguan fault; (7) Pangusi-Fengpei fault; (8) Southern marginal thrust fault belt in the coal-bearing basins in North China; $\mathrm{I}_{1}-$ Northern marginal compressional deformation belt in North China; $\mathrm{I}_{2}-$ Western marginal compressional deformation belt in North China; $\mathrm{I}_{3}-$ Southern marginal compressional deformation belt in North China; $\mathrm{II}_{1}-$ Coalfields in Northern North China; $\mathrm{II}_{2}-$ Western Henan and Xuhuai coalbearing areas in Southern North China; $\mathrm{III}_{1}-$ Weak deformation subarea in the Ordos Basin; $\mathrm{III}_{2}-$ Shanxi block; $\mathrm{III}_{3}-$ Extensional deformation subarea in Eastern North China

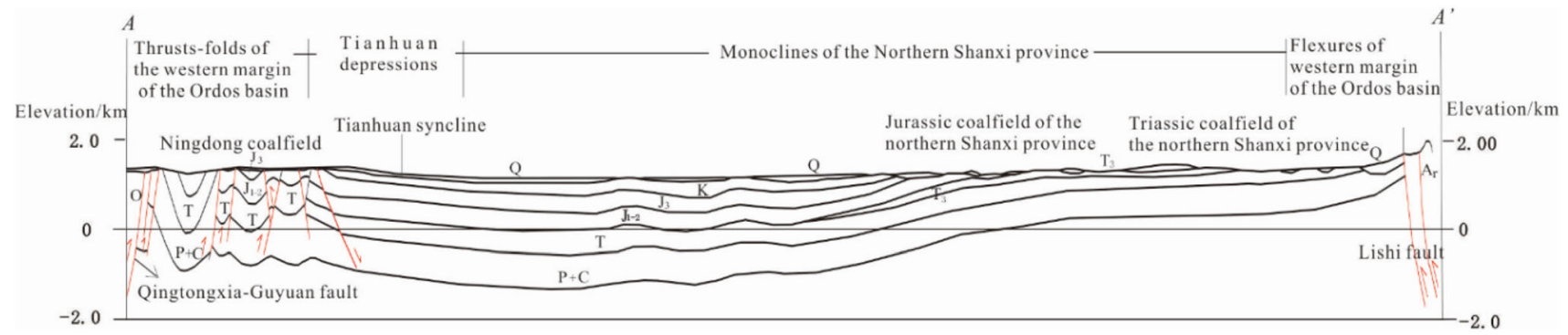

Fig. 6 Structural profile of the $\mathrm{E}-\mathrm{W}$ trending $A-A^{\prime}$ cross section in the Ordos Basin (section position see Fig. 5)

belt on the western margin, a flexural fold belt on the eastern margin, uplift on the northern margin, faultuplift on the southern margin, and the Shanbei monocline and Tianhuan sag. The tectonic deformation is confined to the margins of the Ordos Basin. However, intrabasinal deformation is weak, and the tectonic framework of the main body suggests a large monocline gently dipping westward (Fig. 6). Thrust faults or thrust nappe structures developed on the margin of the Ordos Basin, and the coal measures suffered deformation and uplift. Compressional deformation decreases rapidly from the margin to the basin to the interior, and the basin is characterized by typical concentric annular structural deformation zones. The compressive tectonic belts on the margin of the Ordos Basin were reformed by an extensional tectonic system in the Cenozoic. The resulting morphotectonic pattern is characterized by the adjacent arrangement of a faulted basin and a compressive uplift belt.

(2) The eastern North China COSS is an extensional deformation area, which is characterized by fault 


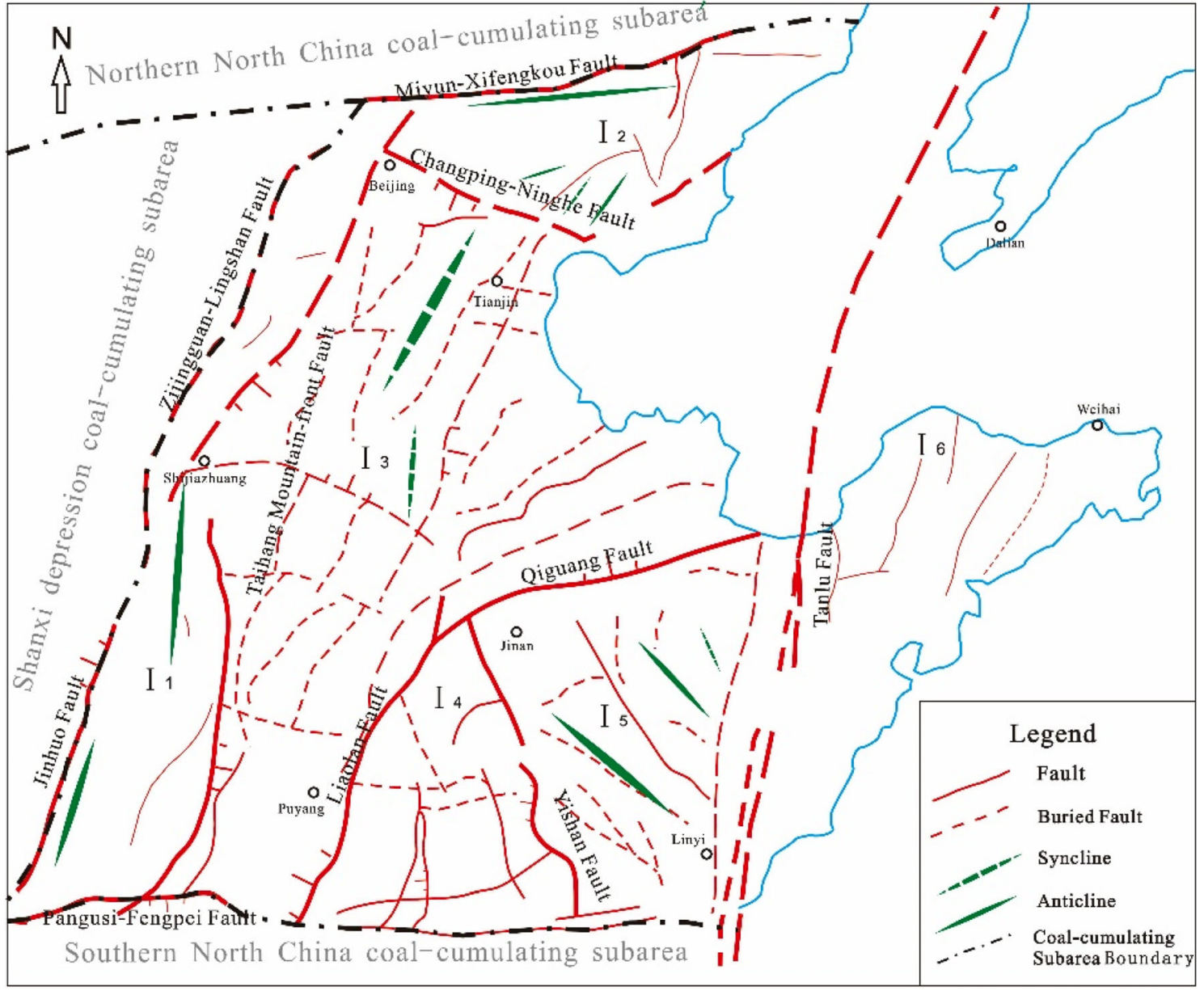

Fig. 7 Diagram of the coalfield structures in the Eastern North China coal occurrence structural subarea. $I_{1}-$ Eastern foothills of the Taihangshan coal occurrence fault block belt; $I_{2}-$ Southern foothills of the Yanshan coal occurrence fold belt; $I_{3}-$ North China plain coal occurrence fault depression belt; $\mathrm{I}_{4}-$ Western Shandong coal occurrence fault depression belt; $\mathrm{I}_{5}$-Central Shandong coal occurrence fault-uplift belt; $\mathrm{I}_{6}-$ Northern Shandong coal occurrence fault depression belt

blocks and covers the Hebei, Shandong, and Anhui provinces east of the Taihang Mountains (Fig. 7). This subarea entered the faulting stage with the continental margin of East Asia in the Late Mesozoic, and a tectonic inversion occurred in degrees. A combination of extensional structures dominated by ladder-like normal faults, graben-horst structures, and half-graben rifts was formed, and the former compressive structural patterns were destroyed.

\subsection{South China coal occurrence structural area}

The South China COSA covers the area of Southern China, which is bounded to the north by the Qinling-Dabie Mountains and to the west by the Longmen MountainJinsha River. Late Permian coal measures developed throughout the area, followed by Late Triassic coal measures, and finally by Neogene coal measures only in the eastern Yunnan area. The South China COSA corresponds to the paleo-continental plate of South China. The basement of this structural area is pieced together from the Yangtze block and an orogenic system known as the Caledonian fold system. Due to the multi-stage nature of the crustal movement from the Late Paleozoic to the present, the coal measures exhibit complicated deformation and significant spatial and temporal differences. It can be divided into the Yangtze COSS and the Cathaysian COSS.

(1) The basic characteristic of the deformation of the coal measures in the Yangtze COSS is the concentric annular structure (Cao et al. 1998), with the Upper Yangtze Sichun Basin as the stable center. The central Sichun coal occurrence structures are characterized by broad and gentle domes, short-axis folds, and sparse faults, and the intensity of the deformation of the coal measures increases outward toward the surrounding areas. There is a coal occurrence thrust belt through Longmen Mountain, 


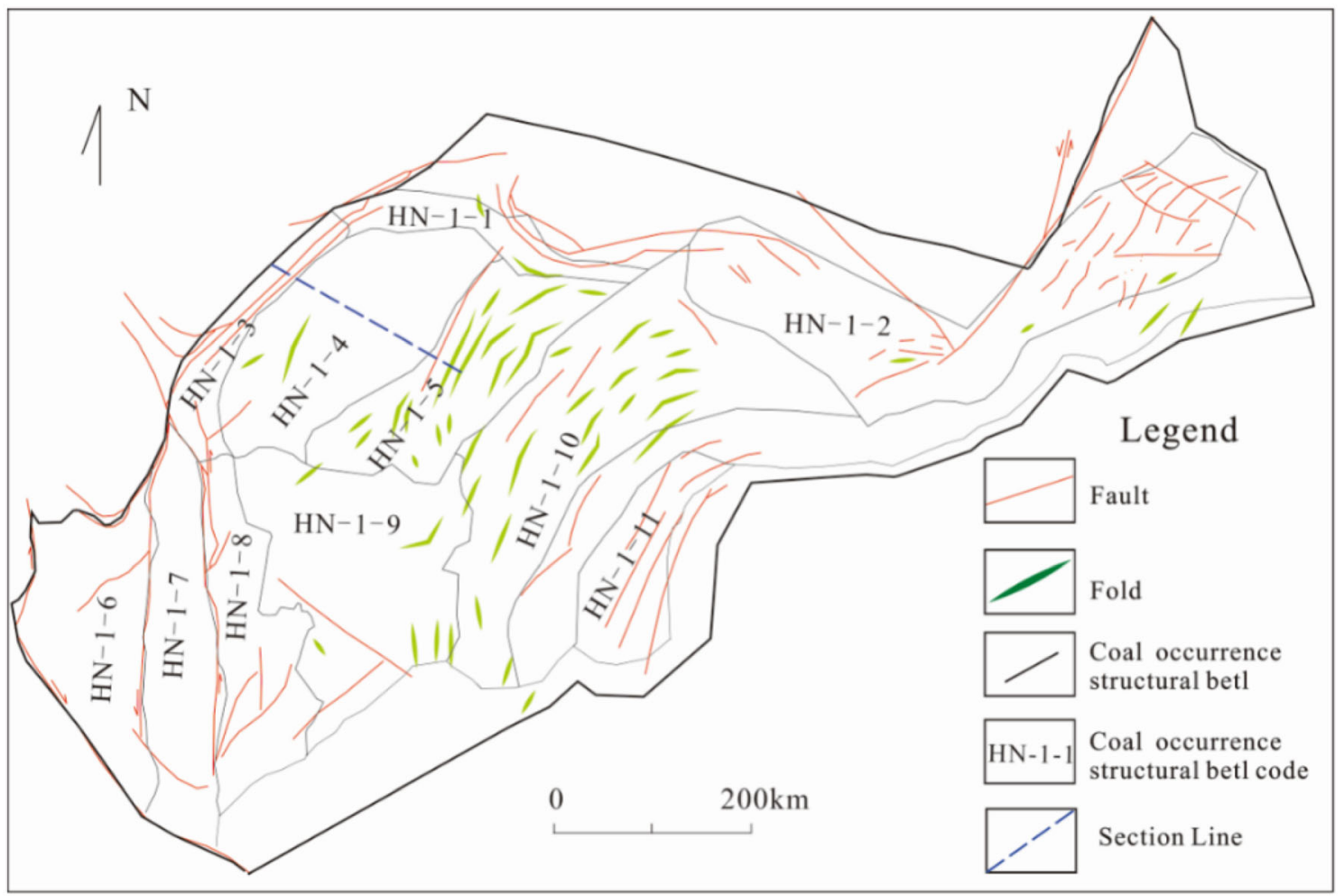

Fig. 8 Distribution of the coal occurrence structural belts in the Yangtze COSS

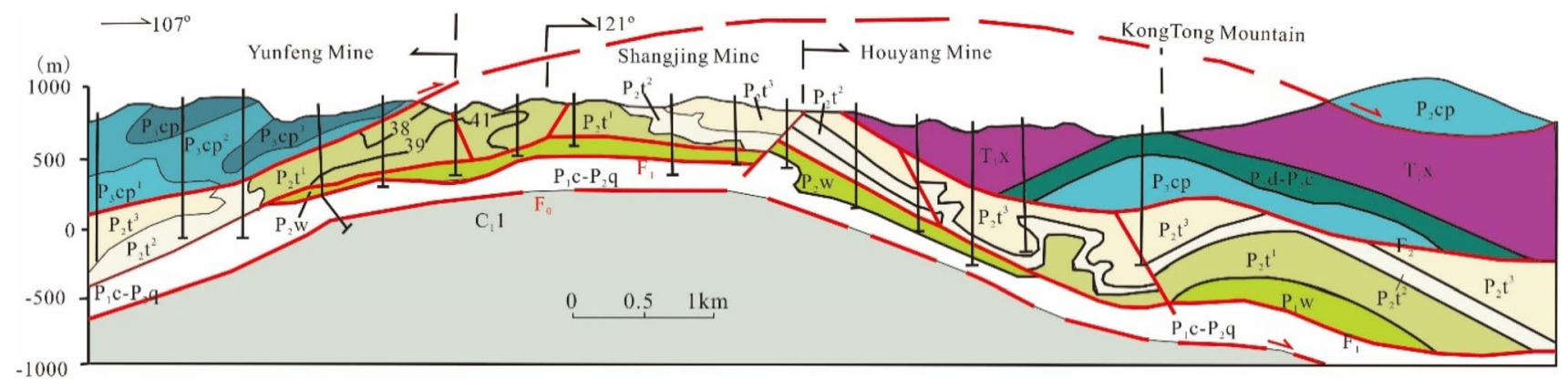

Fig. 9 Geological profile of the Datian Mine in Shangjing County, Fujian, SE China (section position see Fig. 10)

a coal occurrence uplift belt in southern central Sichun, a coal occurrence ejective fold belt in Sichun-Chongqing, a coal occurrence trough-like fold belt in Chongqing-Hubei-Hunan-Guizhou, and a coal occurrence fault-uplift belt in the Jiangnan Orogen (Fig. 8).

(2) The basement of the Cathaysian COSS is composed of pre-Devonian low-grade metamorphic rocks, the activity of which is greater than that of the Yangtze block. Due to the alternating function of the different tectonic mechanisms, e.g., extruding and stretching, since the Late Paleozoic, the deformation of the coal measures is complicated (Wang and Wang 1993; Mao and $\mathrm{Xu}$ 1999). Nappe and gliding nappe structures are widely developed in the coalfields, and the Fujian-Hunan-Jiangxi is famous for its colorful "Red silk dancing-like fold" metaphor (Fig. 9).

Throughout the South China COSA, the intensity of the tectonic deformation and magmatic activity increases from the interior of the plate to the edge of the plate. In addition to this, the structural framework of the coalfield is obviously controlled by regional uplift and depression. From the coastal volcanics in Fujian-Zhejiang to the Yangtze block, a series of large NE-NNE trending uplifts and depressions are arranged in alternating order (Fig. 10). In addition, the combination law of the banding deformation zones and the NE-NNE trending distribution is obvious (Cao et al. 1998; Wang et al. 2007). 


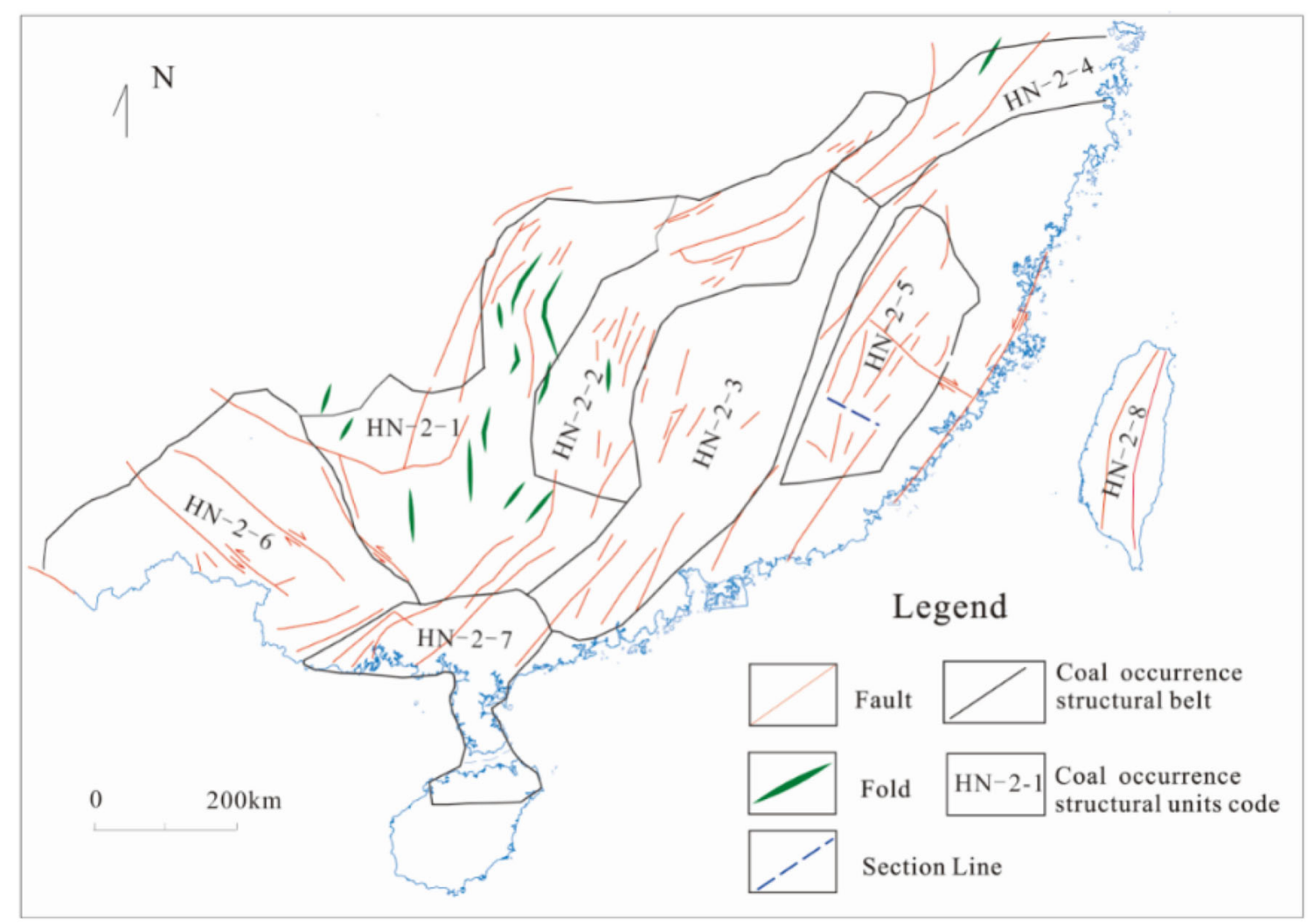

Fig. 10 Distribution of the coal occurrence structural belts in the Cathaysian coal occurrence structural subarea

\subsection{Northwest China coal occurrence structural area}

The Northwest China coal occurrence structural area crosses several first-level tectonic units, such as the Tinashan-Xingmeng orogenic system, the Tarim continental block, and the Qinling-Qilianshan-Kunshan orogenic system. The Early-Middle Jurassic coal-accumulating basin formed in an extensional geodynamic environment, which formed after the orogenic period. Differences in tectonic setting and basement structure resulted in the observed diversity of coal accumulation and later deformation of the coal-bearing basin. Due to the collision of the Indian Plate and the Eurasian Plate since the final stage of the Mesozoic, the basins in northwest China experienced an inversion of different degrees and formed a regenerated foreland basin. The general coal occurrence structures in the coal-bearing basin are described as having a steep edge and flat bottom, i.e., a thrust nappe system developed at the edge of the basin, while the framework of the inner basin is characterized by deeply buried fault blocks with simpler structural deformation. With an extremely large coal occurrence basin as its center, the Northwest China coal occurrence structural area can be divided into three coal occurrence structural units (Fig. 11), the Junggar Basin
COSS, the Tarim Basin COSS, and the Qilianshan-Kunlun Mountains COSS.

(1) The Junggar Basin COSS includes the Junggar coalbearing basin and the Turpan-Hami coal-bearing basin in the Tianshan-Xingmeng orogenic system, with Precambrian crystalline basement throughout. This subarea includes seven coal occurrence structural belts, which exhibit a concentric annular structure within the deformation zones. The degree of structural complexity gradually increases from the center outward. Tight-isoclinal folds and thrust nappe or thrust structures developed on the periphery of the basin, while the coal measures were highly compressed. In contrast, the inner basin was mainly deformed by broad and gentle folds (Fig. 12).

(2) The Tarim Basin COSS is composed of the surrounding orogenic belts and the rigid block between the Tianshan orogenic belt and the Kunlun orogenic belt. Its northern margin and southern margin are the thrust nappe tectonic belts, and the southeast margin is the Altyn fault. The deformation of the coal measures exhibits concentric annular features. The coal measures in the outer annulus are highly deformed and are characterized by tight-isoclinaloverturned folds and associated thrust faults. The 


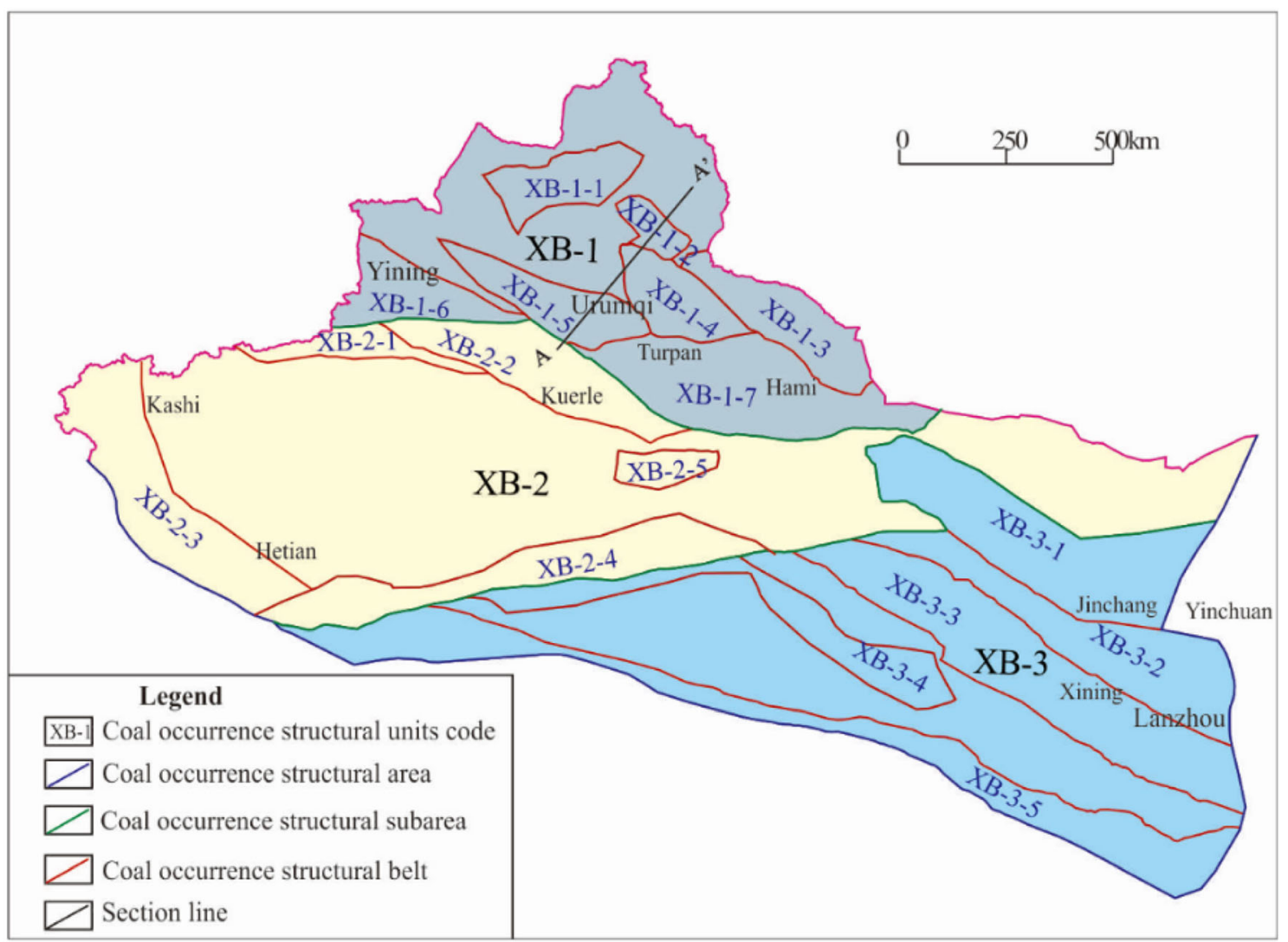

Fig. 11 Division of the coal occurrence structural units in the Northwest China coal occurrence structural area

coal measures are deeply buried in the inner basin and are transferred into a combination of fault blocks, which have wave-like or horizontal strata. The cross sections shave steep edges and a flat bottom or a W-shape (Fig. 13).

(3) The Qilianshan-Kunlun Mountains COSS is bounded on the east by the Erlashan fault and the Liupanshan fault, on the south by the Kunzhong fault, and on the west mainly by the Altyn fault with the Beishan partway across the Altyn fault. This structural subarea covers the distribution area of the Early-Mid Jurassic coal measures within the Qilian orogenic belt and the Qaidam block. Due to the ramp compression deformation environment of this subarea, the coal measures show a parallel banded distribution with an NW-SE trend. The folds and thrust nappe structures are fairly well developed, with gliding structures partially developed, and the coal measures commonly present as fault blocks. Based on the distribution and deformation characteristics of the Early-Mid Jurassic coal measures, this subarea can be divided into several coal occurrence structural belts, which feature parallel banding deformation, i.e., the Alxa fault depression belt, the
Qilian ramp-depression belt, the Hexi corridor rampdepression belt, the Northern Qaidam thrust belt, and the Eastern Kunlun fault-uplift belt (Fig. 14).

\subsection{Yunnan-Tibet coal occurrence structural area}

The Yunnan-Tibet COSA tectonically belongs to the Tethys category, and it has a complicated geological evolution. Taking the Tibet-Sanjiang orogenic system as the main body, this area comprises blocks belonging to the Eurasian continent and the Gandwana continent and the suture zones between them. The coal measures mainly accumulated on the northern Tibetan Plateau and in western Yunnan, and they are mostly small coal-bearing blocks, which are controlled by NW-SE trending deep faults and were destroyed during the later coal-forming period (Tan et al. 2016; Qiao et al. 2019). The intense neo-tectonics formed the highly developed folds and faults in the coalbearing basins. Small-scale coal-bearing blocks, with a scattered distribution, are rarely developed (Fig. 15).

The Yunnan-Tibet COSA can be divided into two coal occurrence structural subareas and six coal occurrence structural belts. 


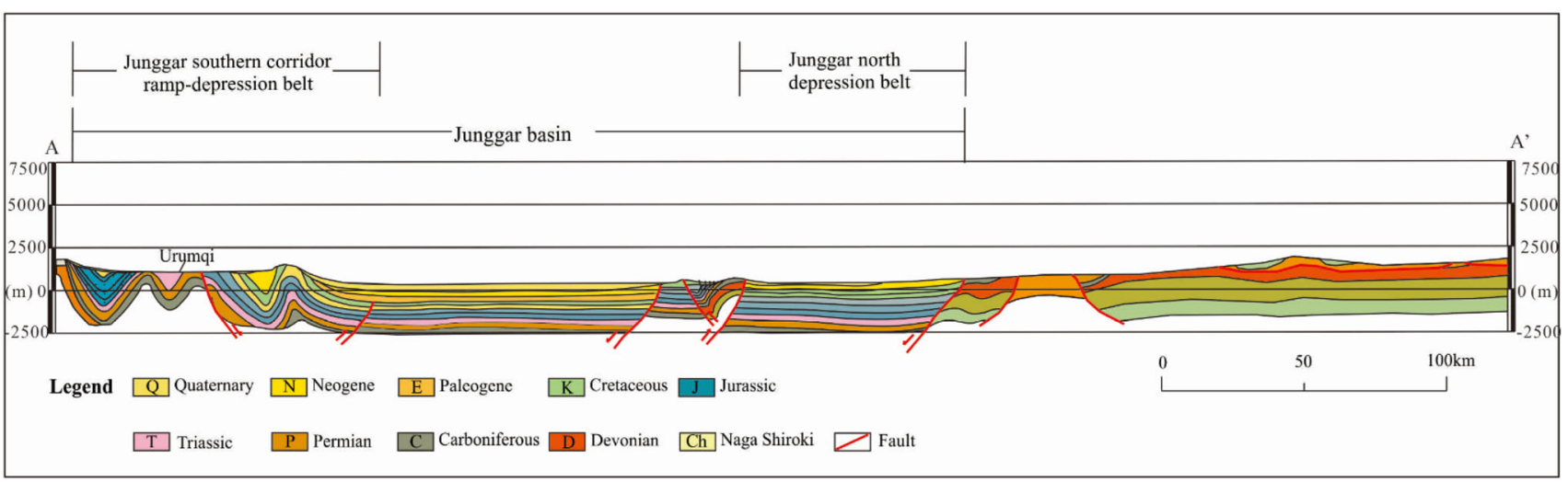

Fig. 12 Structural profile of an N-S trending cross section in the Junggar Basin coal occurrence structural subarea (section position see Fig. 11)

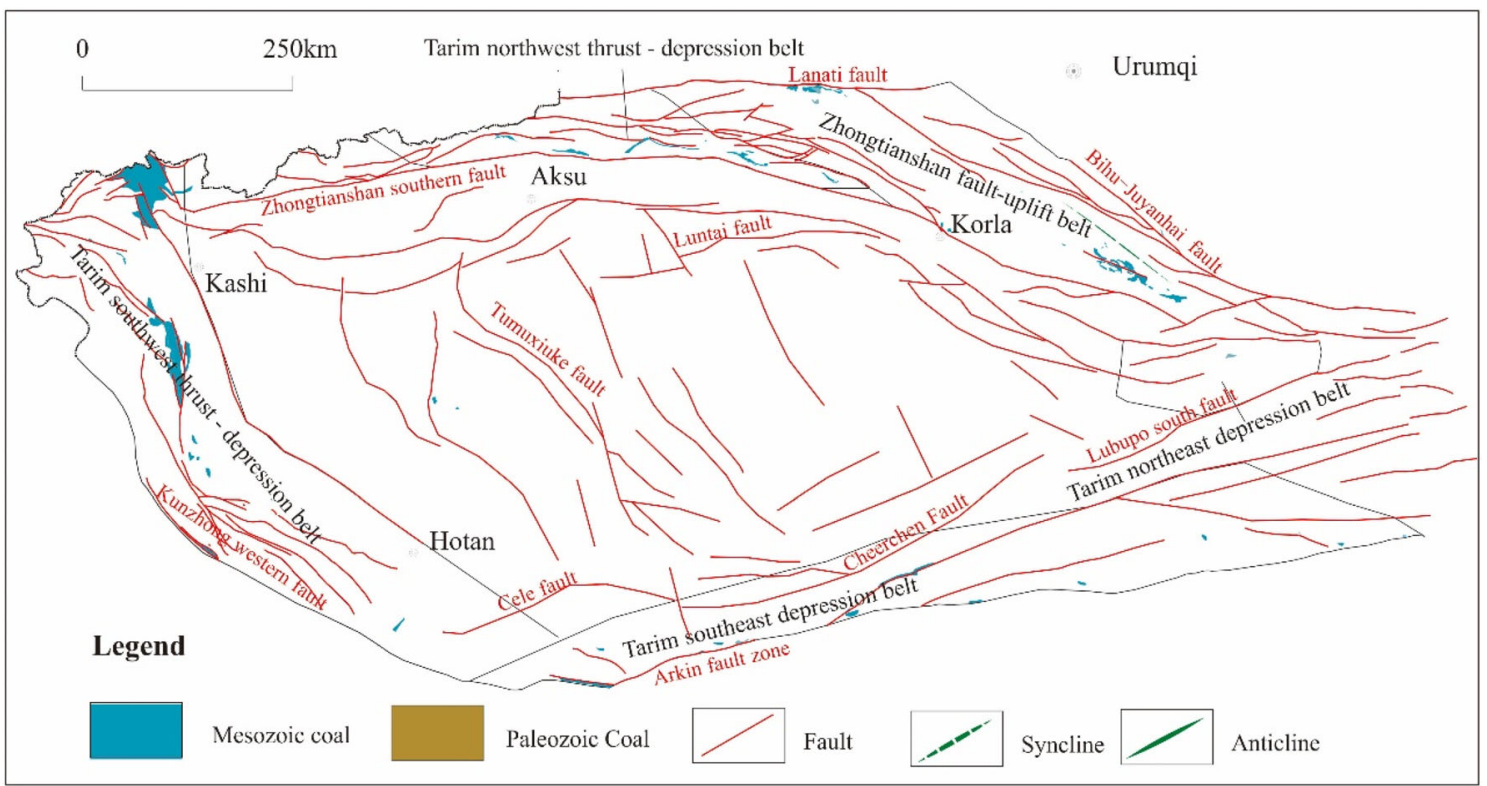

Fig. 13 Diagram of the structural outline in the Tarim Basin coal occurrence structural subarea

(1) The Northern Tibet COSS includes the TumenBaqing fold belt and the Qingnan-Changdu foldthrust belt on the northern Tibetan Plateau. Coal measures of marine-terrigenous facies formed during the Late Paleozoic and the Triassic are mainly located on Tanggula Mountain in the north and in the Changdu block in eastern Tibet. The thickness of the strata, which has poor coal-bearing properties, varies greatly, and the structure of the coal seam is complex. This deposit experienced strong later deformation including the formation of linear folds that are NWW trending thrust nappe structures in the north and NNW trending thrust nappe structures in the east, resulting in fragmented coal-bearing blocks and intensively deformed coal seams.
(2) The Western Yunnan COSS includes the LanpingPuer thrust-fold belt, the Baoshan-Lincang strikeslip fault-subside belt, and the Tengchong-Luxi fault depression belt. The Cenozoic strike-slip faults are significant features, and the Western Yunnan area is controlled by the activity of the fault, with highly developed small-scale intermountain basins. In addition, coal accumulation occurred in the Neogene. Located in a tectonically active belt, the coal-bearing properties of this subarea are greatly inferior to the contemporary basin group in the Eastern Yunan area, which has the Yangtze platform as its basement. 


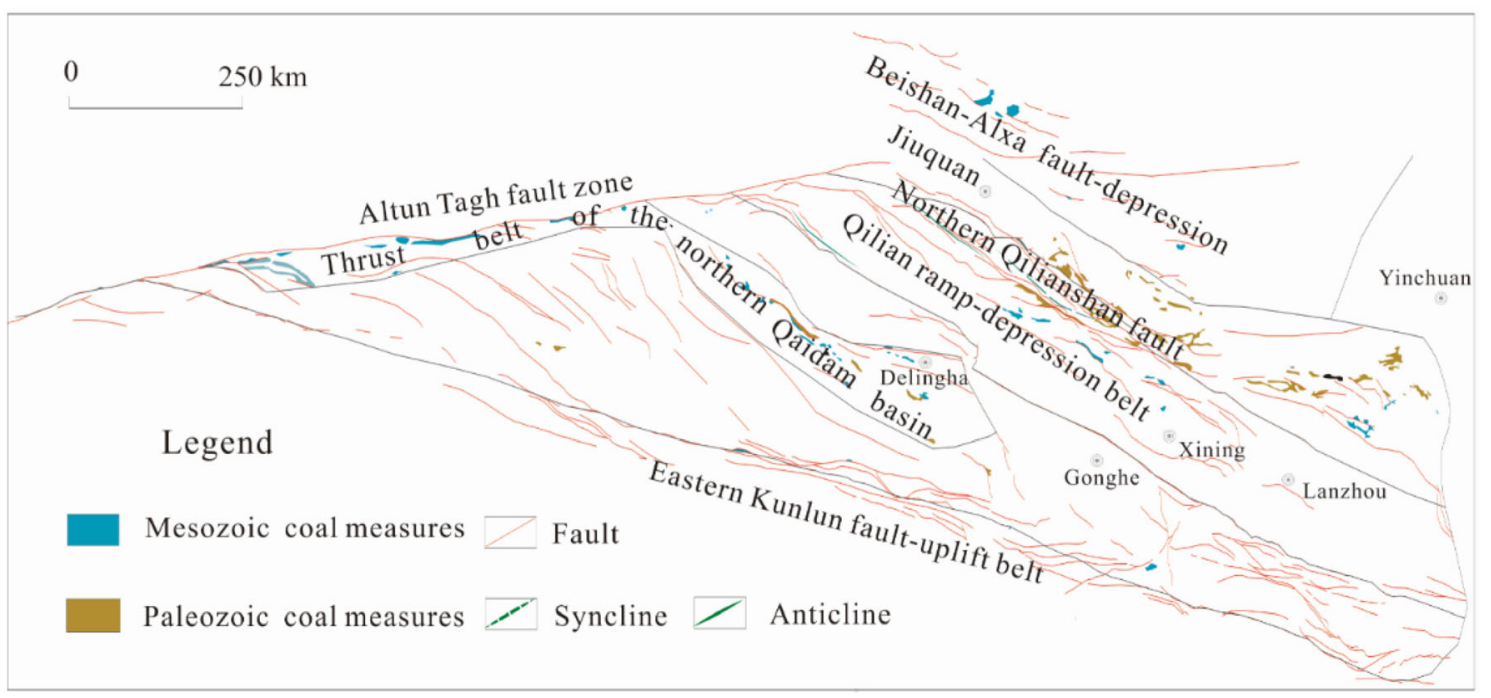

Fig. 14 Diagram of the structural outline in the Qilianshan-Kunlun Mountains coal occurrence structural subarea

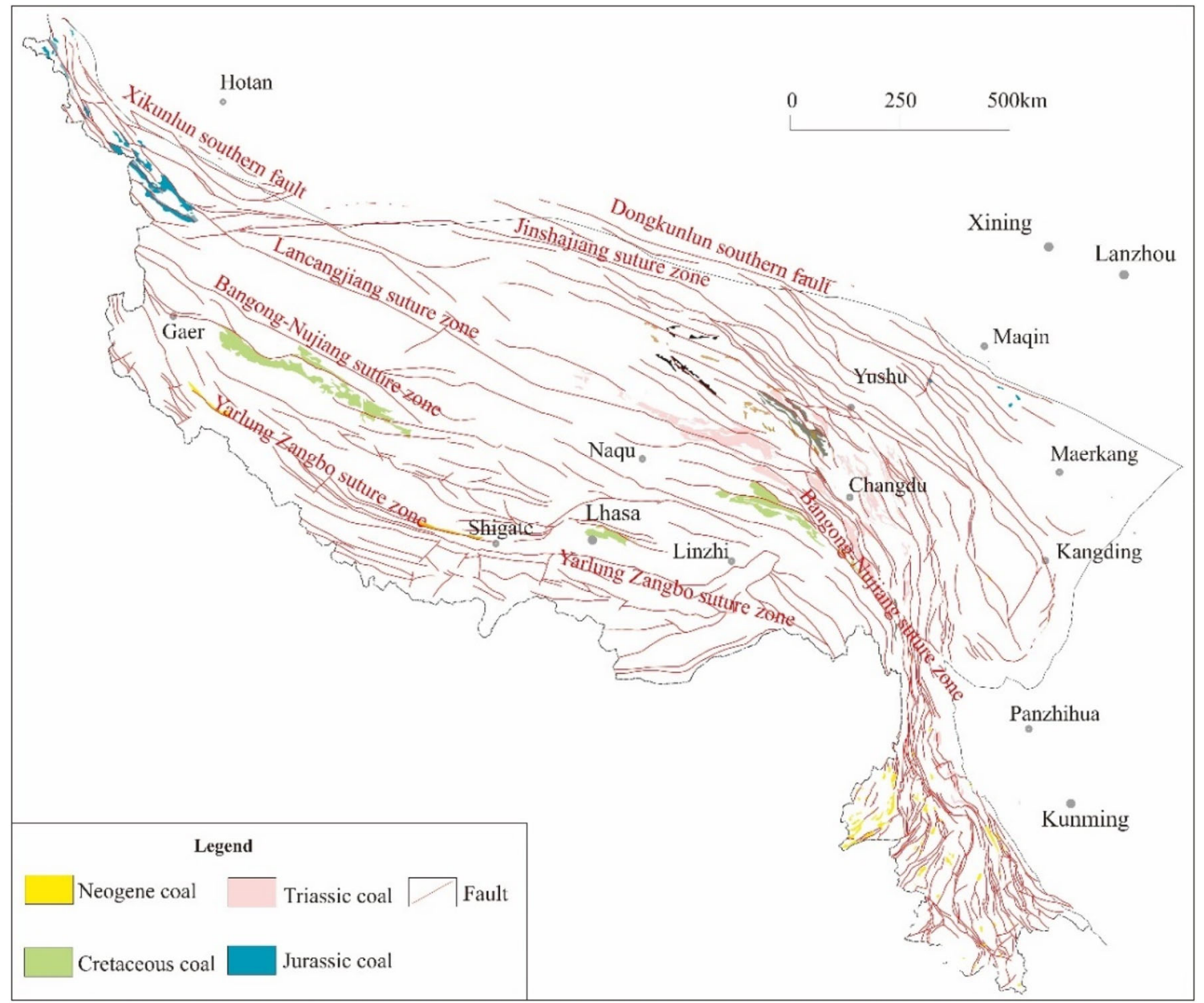

Fig. 15 Diagram of the coalfield structure in the Yunnan-Tibet coal occurrence structural area 


\section{Structural types and evolution of the coal- bearing basins}

The present occurrence status of the coal resources is the result of the synthesis of multiple tectonic movements of coal-bearing basins and coal-bearing strata over an extended time period. The structural-depositional basin that occurs with coal accumulation is known as a coal-forming prototype basin. Then, the coal-forming basin was destroyed, inverted, and superimposed during multiple tectonic movements. The coal-bearing strata underwent deformation and displacement, such as uplift and erosion or subsidence and deep burial, and they lost their original continuity and integrity. It was segmented into coal-bearing blocks with different sizes and depths. Currently, these blocks are the object of resource evaluation, exploration, and development. In fact, the majority of today's coalbearing basins are residual basins, even though they do not have the geometry of a basin, regardless of the geological structure and geographical landscape. Therefore, the term coal occurrence structural unit is recommended to describe the characteristics of the occurrence of coal-bearing strata in the present day, while coal-bearing basin is mainly used to describe a coal-forming prototype basin.

\subsection{Classification index of coal-forming basins}

Researchers in China and abroad have already proposed different classifications for sedimentary basins and coalforming basins based on different perspectives (Lyons and Rice 1986; Beaumont and Tankand 1987; Li 1988; Mang et al. 1994; Ren 1993; Ingersoll and Busby 1995; Liu 2008). Based on the summary of previous studies, the potential evaluation of coal resources in this study was used to conduct a comprehensive study on the classification of coal-forming prototype basins based on seven aspects: the structural pattern, basement properties, morphological structure, the scale of basins, geodynamic environment, paleogeography, and coal accumulation (Table 2).

\subsection{Classification of coal-forming basins in the main coal accumulation periods}

According to the above-described criteria, the comprehensive types of coal-forming basins in the main coal occurrence periods are classified in Tables 3 and 4 .

\subsection{Tectonic evolution of coal-forming basins}

Since the Late Paleozoic, the Chinese continent has experienced four major tectonic cycles: the Hercynian movement, the Indosinian movement, the Yanshan movement,
Table 2 Classification index of coal-forming basins

\begin{tabular}{|c|c|}
\hline Index & Classification and description \\
\hline Structural pattern & $\begin{array}{l}\text { Intracontinental rift, back-arc rift, cratonic } \\
\text { depression, passive continental marginal fault } \\
\text { depression, active continental marginal } \\
\text { depression, foreland basin, intermountain } \\
\text { basin, Strike-slip pull-apart basin }\end{array}$ \\
\hline $\begin{array}{l}\text { Basement } \\
\text { properties }\end{array}$ & $\begin{array}{l}\text { Archean-proterozoic crystalline basement, } \\
\text { paleozoic-mesozoic folded basement }\end{array}$ \\
\hline $\begin{array}{l}\text { Morphological } \\
\text { structure }\end{array}$ & $\begin{array}{l}\text { Depression, fault depression, fault sag, down } \\
\text { warped fault }\end{array}$ \\
\hline Scale & $\begin{array}{l}\text { Giant }>50 \times 10^{4}-100 \times 10^{4} \mathrm{~km}^{2}, \text { Large } \\
\quad 10 \times 10^{4}-50 \times 10^{4} \mathrm{~km}^{2}, \text { Medium } 1 \times 10^{4}- \\
10 \times 10^{4} \mathrm{~km}^{2}, \text { Small }<1 \times 10^{4} \mathrm{~km}^{2}\end{array}$ \\
\hline $\begin{array}{l}\text { Geodynamic } \\
\text { environment }\end{array}$ & Compression, extension, shearing, compound \\
\hline Paleogeography & Continent, marine-continent, marine \\
\hline $\begin{array}{l}\text { Coal } \\
\text { accumulation }\end{array}$ & $\begin{array}{l}\text { Developed in continuous and stable way } \\
\text { throughout, widely developed in relatively } \\
\text { continuous and stable way, partially } \\
\text { developed in a discontinuous and } \\
\text { unstable way }\end{array}$ \\
\hline
\end{tabular}

and the Himalayan movement. The differences in tectonic movements and tectonic positions determined the different types of coal-forming basins in the different coal occurrence periods, while the different tectonic movements after the coal forming activities resulted in differences in tectonic evolution and the later deformation of coal-forming basins. According to the severity of the damage to the structures of the coal-forming basins, today's coal-bearing basins, which are called residual basins, can be divided into three types: weakly deformed, transitional, and highly deformed (Mang et al. 1994). By utilizing the fact that coal-forming prototype basins, which experienced polycyclic tectonic movements, can turn into coal occurrence structural units through different levels of decomposition, destruction, inversion, and superposition, the corresponding relationship between the major coal-forming basins and the coal occurrence structural units was established and was used to reveal the formation and evolution of the structural framework of coalfields.

\section{Coal-controlling structural patterns}

\subsection{Structural control on coal}

Coalfield geologists in China have been aware of the full control of structures on the formation and deformation of coal beds for a long time, and gradually, the concept of structural control on coal was formed (Han and Yang 1980; 
Table 3 Comprehensive types of coal-forming basins in the Late Paleozoic

\begin{tabular}{|c|c|c|c|c|c|c|c|}
\hline Basin & $\begin{array}{l}\text { Structural } \\
\text { pattern }\end{array}$ & Basement property & Structure & $\begin{array}{l}\text { Geodynamic } \\
\text { environment }\end{array}$ & Scale & Paleogeography & $\begin{array}{l}\text { Coal } \\
\text { accumulation }\end{array}$ \\
\hline $\begin{array}{l}\text { Hexi } \\
\text { Corridor } \\
\text { Basin }(\mathrm{C}- \\
\mathrm{P})\end{array}$ & $\begin{array}{l}\text { Active } \\
\text { continental } \\
\text { marginal } \\
\text { basin }\end{array}$ & $\begin{array}{l}\text { Proterozoic crystalline } \\
\text { basement, Caledonian } \\
\text { folded basement }\end{array}$ & $\begin{array}{l}\text { Down } \\
\text { warped } \\
\text { fault }\end{array}$ & Compression & Small & $\begin{array}{l}\text { Marine- } \\
\text { Continent }\end{array}$ & $\begin{array}{l}\text { Unstable and } \\
\text { discontinuous }\end{array}$ \\
\hline $\begin{array}{l}\text { South China } \\
\text { Basin }(\mathrm{C})\end{array}$ & $\begin{array}{l}\text { Intracontinental } \\
\text { rift }\end{array}$ & Caledonian folded basement & $\begin{array}{l}\text { Fault } \\
\quad \text { depression }\end{array}$ & Extension & Medium & $\begin{array}{l}\text { Marine- } \\
\text { Continent }\end{array}$ & $\begin{array}{l}\text { Relatively } \\
\text { stable and } \\
\text { continuous }\end{array}$ \\
\hline $\begin{array}{l}\text { North China } \\
\text { Basin (C- } \\
\text { P) }\end{array}$ & $\begin{array}{l}\text { Cratonic } \\
\text { depression }\end{array}$ & $\begin{array}{l}\text { Archean-Proterozoic } \\
\text { crystalline basement }\end{array}$ & Depression & Compression & Giant & $\begin{array}{l}\text { Marine- } \\
\text { Continent }\end{array}$ & $\begin{array}{l}\text { Stable and } \\
\text { Continuous }\end{array}$ \\
\hline $\begin{array}{l}\text { Yangtze } \\
\quad \text { Basin }(\mathrm{P})\end{array}$ & $\begin{array}{l}\text { Cratonic } \\
\text { depression }\end{array}$ & $\begin{array}{l}\text { Archean-Proterozoic } \\
\text { crystalline basement }\end{array}$ & Depression & Extension & Large & $\begin{array}{l}\text { Marine- } \\
\text { Continent }\end{array}$ & $\begin{array}{l}\text { Stable and } \\
\text { Continuous }\end{array}$ \\
\hline $\begin{array}{l}\text { Southeast } \\
\text { China } \\
\text { Basin (P) }\end{array}$ & $\begin{array}{l}\text { Intracontinental } \\
\text { rift }\end{array}$ & Caledonian folded basement & Depression & Extension & Large & $\begin{array}{l}\text { Marine- } \\
\text { Continent }\end{array}$ & $\begin{array}{l}\text { Relatively } \\
\text { continuous }\end{array}$ \\
\hline $\begin{array}{l}\text { Qiangtang- } \\
\text { Changdu } \\
\text { Basin }\end{array}$ & $\begin{array}{l}\text { Active } \\
\text { continental } \\
\text { marginal } \\
\text { basin }\end{array}$ & Yanshanian folded basement & $\begin{array}{l}\text { Fault } \\
\quad \text { depression }\end{array}$ & Extension & Small & Marine & Unstable \\
\hline
\end{tabular}

Table 4 Comprehensive types of coal-forming basins in the Late Triassic

\begin{tabular}{|c|c|c|c|c|c|c|c|}
\hline Basin & $\begin{array}{l}\text { Structural } \\
\text { pattern }\end{array}$ & Basement property & Structure & $\begin{array}{l}\text { Geodynamic } \\
\text { environment }\end{array}$ & Scale & Paleogeography & $\begin{array}{l}\text { Coal } \\
\text { accumulation }\end{array}$ \\
\hline $\begin{array}{l}\text { Main body of } \\
\text { Ordos Basin (T3) }\end{array}$ & $\begin{array}{l}\text { Cratonic } \\
\text { depression }\end{array}$ & $\begin{array}{l}\text { Archean- } \\
\text { Palaeoproterozoic } \\
\text { crystalline basement }\end{array}$ & $\begin{array}{l}\text { Fault } \\
\quad \text { depression }\end{array}$ & Compression & Medium & Continent & $\begin{array}{l}\text { Stable } \\
\text { Partial }\end{array}$ \\
\hline $\begin{array}{l}\text { Western Ordos } \\
\text { Basin (T3) }\end{array}$ & Foreland basin & $\begin{array}{l}\text { Archean- } \\
\text { Palaeoproterozoic } \\
\text { crystalline basement }\end{array}$ & $\begin{array}{l}\text { Fault } \\
\quad \text { depression }\end{array}$ & Compression & Small & Continent & $\begin{array}{l}\text { Stable } \\
\text { Partial }\end{array}$ \\
\hline $\begin{array}{l}\text { Northern Tarim } \\
\text { Basin (T3) }\end{array}$ & $\begin{array}{l}\text { Peripheral } \\
\text { foreland } \\
\text { basin }\end{array}$ & $\begin{array}{l}\text { Proterozoic crystalline } \\
\text { basement }\end{array}$ & $\begin{array}{l}\text { Fault } \\
\quad \text { depression }\end{array}$ & Compression & Medium & Continent & $\begin{array}{l}\text { Relatively } \\
\text { stable and } \\
\text { continuous }\end{array}$ \\
\hline $\begin{array}{l}\text { Hunan-Jiangxi- } \\
\text { Guangdong } \\
\text { Basin (T3) }\end{array}$ & $\begin{array}{l}\text { Intermountain } \\
\text { basin }\end{array}$ & $\begin{array}{l}\text { Caledonian folded } \\
\text { basement }\end{array}$ & $\begin{array}{l}\text { Fault } \\
\text { depression }\end{array}$ & Compression & Medium & $\begin{array}{l}\text { Marine- } \\
\text { Continent }\end{array}$ & $\begin{array}{l}\text { Relatively } \\
\text { stable and } \\
\text { continuous }\end{array}$ \\
\hline Sichuan Basin (T3) & $\begin{array}{l}\text { Cratonic } \\
\text { depression }\end{array}$ & $\begin{array}{l}\text { Proterozoic crystalline } \\
\text { basement }\end{array}$ & $\begin{array}{l}\text { Fault } \\
\quad \text { depression }\end{array}$ & Compression & Large & $\begin{array}{l}\text { Marine- } \\
\text { Continent }\end{array}$ & $\begin{array}{l}\text { Relatively } \\
\text { stable and } \\
\text { continuous }\end{array}$ \\
\hline $\begin{array}{l}\text { Chuxiong Basin } \\
\text { (T3) }\end{array}$ & Foreland basin & $\begin{array}{l}\text { Proterozoic crystalline } \\
\text { basement }\end{array}$ & $\begin{array}{l}\text { Fault } \\
\quad \text { depression }\end{array}$ & Compression & Medium & $\begin{array}{l}\text { Marine- } \\
\text { Continent }\end{array}$ & $\begin{array}{l}\text { Relatively } \\
\text { stable and } \\
\text { continuous }\end{array}$ \\
\hline $\begin{array}{l}\text { Qiangtang- } \\
\text { Changdu Basin } \\
\text { (T3) }\end{array}$ & $\begin{array}{l}\text { Intermountain } \\
\text { basin }\end{array}$ & $\begin{array}{l}\text { Indosinian folded } \\
\text { basement }\end{array}$ & $\begin{array}{l}\text { Down } \\
\text { warped } \\
\text { fault }\end{array}$ & Compression & Small & Marine & Unstable \\
\hline
\end{tabular}

Huang and Xia 1991; Gao et al. 1996). The meaning of the structural control on coal can be understood in two ways. In a broad sense, the structural control on coal indicates the control of tectonics on the accumulation and preservation of coal. In a narrow sense, structural control indicates the control of the structural features and structural deformation on the formation and occurrence of coal.

The formation and evolution of structures in coalfields is a process consisting of several stages of decomposition and destruction of coal-forming prototype basins by tectonics, 
Table 5 Coal-controlling structural styles

\begin{tabular}{|c|c|c|c|}
\hline Style & Type & Style & Type \\
\hline \multirow[t]{8}{*}{ Extensional structural styles } & \multirow[t]{2}{*}{ Monoclinic fault block } & \multirow[t]{8}{*}{ Shearing and rotational structural styles } & Sinistral strike-slip fault \\
\hline & & & Dextral strike-slip fault \\
\hline & \multirow[t]{2}{*}{ Graben } & & Normal strike-slip fault \\
\hline & & & Reversed strike-slip fault \\
\hline & Horst & & En echelon folds \\
\hline & Tilted fault block & & Flower structure \\
\hline & \multirow[t]{2}{*}{ Half graben } & & S-shaped structure \\
\hline & & & Reversed S-shaped structure \\
\hline \multirow[t]{15}{*}{ Compressional structural styles } & Buckling fold & \multirow[t]{6}{*}{ Inversion structural styles } & Rotational structure \\
\hline & Bending fold & & Positive inversion fault \\
\hline & Ejective fold & & Negative inversion fault \\
\hline & Trough-like fold & & Positive inversion fold \\
\hline & Superimpose fold & & Negative inversion folds \\
\hline & Fault bend fold & & Compound inversion \\
\hline & Fault propagation fold & \multirow[t]{6}{*}{ Sliding structural styles } & Tilted fault block type \\
\hline & Detachment fold & & Thrust-fold type \\
\hline & Imbricated structure & & Block rotation type \\
\hline & Duplex structure & & Gravity gliding type \\
\hline & Thrust sheet & & Dome type \\
\hline & Horsts & & Interlayer gliding \\
\hline & Compressional fault block & \multirow[t]{3}{*}{ Syn-depositional structural styles } & Growth fault \\
\hline & Pop-up & & Syn-depositional anticline \\
\hline & Triangle zone & & Syn-depositional syncline \\
\hline
\end{tabular}

deformation, and the displacement of coal measures and coal seams; the loss of original continuity and integrity; and formation of separate coal occurrence structural units and coal-bearing blocks. From the perspective of the evaluation and prospecting of resources, structural patterns play a decisive role in the occurrence of coal seams. Therefore, from the perspective of the development and utilization of coal resources, special attention was paid to the control of structural features or structural deformation on the occurrence status of coal seams, and the concept of coal-controlling structural styles was proposed (Cao 2007).

\subsection{Coal-controlling structural styles and their basic types}

Structural styles are the general features and patterns of a group of structures or certain structural characteristics, i.e., the summation of tectonic deformation during the same period or structures formed under the same stress. The purpose of the study of structural styles is to reveal the law of development of geological structures and to establish a geological structural model. Therefore, when geological exploration data are insufficient, a possible tectonic framework can be determined, and the prediction of structures can be made based on the structural styles. The concept of structural styles has been widely used in the structural study of orogenic belts and basins (Harding and Lowell 1979; Suo 1985; Lowell 1985; Liu 1993).

Coal-controlling structural styles are proposed according to the evaluation and development of coal resources, the characteristics of the structural styles that control the formation, and the tectonic evolution and occurrence status of coal measures and coal seams. They are the important components of regional structural styles, but they are not the only ones.

Classification of coal-controlling structural styles was carried out using geodynamic classification. Based on the synthesis of the results of the potential evaluation of coal resources in every province, the classification of coalcontrolling structural styles was further improved (Cao 2007; Cheng et al. 2010), and it can be summarized into six groups of coal-controlling structural styles: extensional structural styles, compressional structural styles, shearing and rotational structural styles, inversion structural styles, sliding structural styles, and syn-depositional structural styles (Table 5). 


\subsection{Distribution of coal-controlling structural styles}

With coal resources widely distributed throughout China, the spatial and temporal difference in the tectonic evolution of coal-forming basins is significant, and as the basic element of the structural control on coal, coal-controlling structural styles are the comprehensive result of the different tectonics that occurred during the geological evolution of the coal measures. The distribution of the coalcontrolling structural styles varies in the different coal occurrence structural units, and thus, they determine the key to the use of structural study for the evaluation of coal resources.

(1) The Northeast COSA is dominated by extensional structural styles, and compressional structural styles and positive inversions are developed in the eastern coal occurrence structural subarea, with strike-slip structural styles developed along the Tanlu fault.

(2) The North China COSA features a concentric annular structure of deformation zones. The edge of this area mainly developed compressional structural styles. In contrast to this, the extensional structural styles are mainly developed inside. Negative inversion is widely developed in the eastern North China coal occurrence structural subarea, and the western Henan coal-bearing area, which is located in the southern North China coal occurrence subarea, is famous for sliding structural styles.

(3) The South China COSA has relatively structurally complex coalfields and is dominated by compressional structural styles and positive inversion. Especially in eastern South China, decollements, which have a gently dipping fault as the key structure, are widely developed. This is a key element in determining the occurrence status of coal measures and the effect of coal prospecting.

(4) The Northwest China COSA is mainly dominated by compressional structural styles and positive inversion, while the North Xinjiang coal occurrence structural subarea, which is mainly composed of the Junggar Basin, and the South Xinjiang coal occurrence structural subarea, which is mainly composed of the Tarim Basin, feature a concentric annular structure of deformation zones. Thrust folds are located at the edges of the basins, and the basin interiors are dominated by fault blocks.

(5) The Yunnan-Tibet COSA is dominated by compressional structural styles, while shearing structural styles are developed in the western Yunnan coal occurrence structural subarea.

\section{Conclusions}

Potential evaluation of coal resources was carried out based on the current occurrence status of coal measures and coal seams. The original coal seams, which had horizontal and continuous distributions, experienced later tectonic movements and were segmented into coal-bearing blocks of different sizes and depths by deformation and displacement. These blocks are the object of resource evaluation, exploration, and development. The complexity of the geological conditions in China results in significant spatial and temporal differences in the tectonic frameworks of its coalfields. Consequently, strengthening the structural study of coalfields and clearly determining the structural factors controlling the occurrence status of coal measures is necessary for the potential evaluation of coal resources.

Acknowledgements This study was financially supported by the Geological Survey Project of China Geological Survey National Potential Evaluation of Coal Resources project (121211121043) and the National Natural Science Foundation of China (41572141, 41772156).

\section{Compliance with ethical standards}

Conflict of interest The authors declare no competing financial interest.

Open Access This article is licensed under a Creative Commons Attribution 4.0 International License, which permits use, sharing, adaptation, distribution and reproduction in any medium or format, as long as you give appropriate credit to the original author(s) and the source, provide a link to the Creative Commons licence, and indicate if changes were made. The images or other third party material in this article are included in the article's Creative Commons licence, unless indicated otherwise in a credit line to the material. If material is not included in the article's Creative Commons licence and your intended use is not permitted by statutory regulation or exceeds the permitted use, you will need to obtain permission directly from the copyright holder. To view a copy of this licence, visit http://creativecommons. org/licenses/by/4.0/.

\section{References}

Beaumont C, Tankand AJ (1987) Sedimentary Basin-forming mechanism. Can Soc Pet Geol Mem 12:117-146

Cao DY (2007) Structural deformation and coal-controlling structural styles in coalfields. New developments of coal resources and safely mining technology. China Coal Industry Publishing House, Beijing, pp 1-6

Cao DY (2018) Tectonnic framework of coalfields and tectonic control of coalseams in China. Science Press, Bejing

Cao DY, Jing YL, Qiu GZ, Zhang DM, Wang Y (1998) Zoning of deformation of coal measures in China. J China Coal Soc 23(5):449-454

Cao DY, Zhang SR, Mu XS, Fu ZH (1999) Study on control factors of deformation of coal measures in China. J China Univ Min Technol 28(1):25-28 
Cao DY, Tan JQ, Chen LM, Guo AJ, Li HT, Liu K (2013) Coal resources potential evaluation and coal occurrence tectonics in China. Coal Sci Technol 41(7):5-9

Cao DY, Guo AJ, Chen LM, Li HT, Liu K, Tan JQ (2016) New interpretation of coalfield tectonic evolution: from coal-forming basins to coal-bearing tectonic units. Coal Geol Explor 44(1):1-8

Che ZC, Luo JH, Liu L (2012) Regional tectonics in China and surrounding areas, 2nd edn. Science Press, Bejing

Cheng AG, Cao DY, Yuan TX (2010) Technical requirements for coal resources potential evaluation. Geological Publishing House, Beijing

Cheng AG, Cao DY, Yuan TX (2016) China occurrence regularity of coal resources and resource evaluation. Science Press, Beijing

Gao WT, Cao DY, Qian GM (1996) Types of structural control on coal. Coal Geol Explor 6:19-24

Han DX, Yang Q (1980) Coalfield geology in China (Second part). China Coal Industry Publishing House, Beijing

Harding TP, Lowell JD (1979) Structural styles, their plate tectonic habitats and hydrocarbon traps in petroleum provinces. AAPG Bull 63:1016-1058

Huang KX, Xia YC (1991) Generality of structural control on coal. China Coal Industry Publishing House, Beijing

Ingersoll RV, Busby CJ (1995) Tectonic of sedimentary basins. Tectonic of sedimentary basins. Cambridge, Blakwell Science, pp 1-51

Li ST (1988) Faulted basin analysis and coal accumulation rules. Geological Publishing House, Beijing

Li TD (2006) Main advances and achievement in the special-subject study of the 3D lithospheric structure of China. Geol China 33:689-699

Liu HF (1993) Dynamic classification of sedimentary basins and their structural styles. Earth Sci J China Univ Geosci 18(6):699-724

Liu CY (2008) Dynamics of sedimentary basin and basin reservoir (ore) forming system. J Earth Sci Environ 30:1-23
Lowell JD (1985) Structural styles in petroleum exploration. OGCI, Tulsa, pp 1-43

Lyons PC, Rice CL (1986) Paleoenvironmental and tectonic controls in coal-forming basins of United States. Geological Society of America Special Paper 210

Ma WP (1992) Analysis of regional tectonics—methodology and China block tectonics. Geological Publishing House, Beijing

Mang DH, Yang BZ, Lin ZP (1994) Coal-bearing basin structures in China. Geological Publishing House, Bejing

Mao JH, Xu HL (1999) Prediction and evaluation of coal resources in China. Science Press, Beijing

Qiao JW, Wu GQ, Song SY (2019) Coal occurrence law and resource potential evaluation in Qinghai-Tibet Plateau. Science Press, Beijing

Ren WZ (1993) Principle and methodology in coal-bearing basin analysis. China Coal Industry Publishing House, Beijing

Ren JS, Chen TY, Niu BG (1990) Tectonic evolution of the continental lithosphere and metallogeny in Eastern China and adjacent areas. Science Press, Beijing

Suo ST (1985) Tectonic analysis. China University of Geosciences Press, Wuhan

Tan JQ, Ma ZK, Gao KF, Song SY, Cao DY (2016) Control effect of plate tectonics on coal measures in northern Qinghai-Tibet Plateau. J China Coal Soc 41(2):286-293

Wan TF (2011) Tectonics in China. Geological Publishing House, Beijing

Wang WJ, Wang X (1993) Nappe, decollement structure and coal prospecting in eastern China. China University of Mining and Technology Press, Xuzhou

Wang GL, Ju YW, Zheng ML (2007) Energy basin tectonics in northern China. China University of Mining and Technology Press, Xuzhou 